\title{
Work-related Stress in Australia: The Effects of Legislative Interventions and the Cost of Treatment
}

Robert Guthrie*, Marina Ciccarelli** and Angela Babic***

Curtin University of Technology

*Professor of Workers Compensation and Workplace Laws - School of Business Law and Taxation Curtin University of Technology Western Australia rob.guthrie@cbs.curtin.edu.au

**Senior Lecturer School of Occupational Therapy and Social Work; Senior Research Fellow - Centre for Research into Disability and Society; Curtin Health Innovation Research Institute - Curtin University of Technology.

$\underline{\text { m.ciccarelli@.curtin.edu.au }}$

***Associate Lecturer School of Business Law and Taxation Curtin University of Technology Western Australia

a.babic@cbs.curtin.edu.au 
Abstract

The Australian Institute of Health and Welfare data published in 2002 shows a continued rise in health care costs to the Australian community due to the growing number of people diagnosed with mental health disorders. Those mental health disorders may originate from a number of sources, including work and non-work-related factors. So called work-related stress claims in all Australian jurisdictions are the most expensive form of workers compensation claim. In the most part this is due to the lengthy period of absence (duration) and complicated medical care which are characteristic of these claims. In Australia, in the last decade, attempts have been made to reduce the costs of compensable stress related claims by imposing special legislative thresholds on such claims. This 'back end' approach to cost reduction has resulted in an array of legislative formula designed to exclude work related stress claims. This article surveys the various legislative provisions dealing with work-related stress claims in Australia and provides an analysis of their effectiveness. A range of options are presented as alternatives to the exclusion of particular forms of work related stress claims. The use of a corporate citizenship approach to the prevention and management of stress claims is also discussed as a proactive alternative to occupational safety and health legislative provisions and the workers compensation legislative exclusions.

\section{Introduction}

Mental health disorders have been described as "a disturbance of mood or thought that can affect behaviour and distress the person or those around them, so that the person cannot function normally" (AIHW, 2002). The International Classification of Diseases 10th revision (ICD-10), Classification of Mental and Behavioural Disorders refers to mental disorders as 'the existence of a clinically recognisable set of symptoms or behaviour associated in most cases as distress and with interference with personal functions' (WHO, 1992). Commonly mental disorders affect a person's capacity to carry out their usual activities such as work and employment. Although mental disorder is of course found in the community in general there has been growing awareness of the costs 
of mental disorders which are caused by or contributed to by work.(Dollard et al,2002) Dollard and Winefield in a survey of the effects of work or the lack of it upon public health concluded that;

Recent modern work environments are increasingly characterised by 'too much work', 'not enough work' and 'no work' due to economic rationalism and local imperative. Each of these unfavourable work states, emerging themselves from the way jobs are constituted, constructed and managed, has been associated with economic and social costs (for example family issues), and increased risk of stress-related disorders and mental health problems. (Dollard \& Winefield, 1996)

As to the direct economic costs of mental health, Australian data, collected by the Safe Work Australia shows a general trend of increased workers compensation claims, as well as increased duration of claims and claims costs in relation to stress-related conditions and mental disorders. For example the number of claims for mental disorders (which is a proxy for work related stress claims) in Australia increased from 5700 in 1997/8 to 8260 in 2004/5. This is against a background of generally declining claims in relation to other forms of injury and diseases suffered at work. In other words this represents not just a rise in compensable claims but a proportionate rise in mental health disorder claims as against all other workers compensation claims. Likewise for the $1997 / 8$ to $2004 / 5$ the median time lost for mental disorders suffered at work rose from 6.8 weeks absence per claim to 9.7 weeks per claim. The peek period was $2001 / 2$ with a median duration per mental disorder clam of 10.6 weeks. The causes of mental stress were classified by Safe 
Work Australia by allocation of incidence with reference to number of mechanisms, including exposure to a traumatic event or occupational violence, harassment, work pressure, workplace bullying, suicide or attempted suicide and other factors. In effect claim types with fall into the categories of physical-mental claims (such as trauma leading to a psychological sequel), and mental-mental claims (such as harassment, workload pressure and bullying). These classifications are generally consistent with academic literature which notes the stressors may be physical or psychological and may affect physical and psychological health. A person's state of health may also act as a stressor as it may sensitise a person to other sources of stress by reducing the ability to cope (Dollard et al. 2002). The leading mechanism for a mental stress claim is work pressure which also has the highest median absence from work rate of 17 weeks per claim (in 2000/1). Interestingly those workers who made claims for exposure to a traumatic event or occupational violence were absent from work for approximately half the time of their colleagues who made claims for work pressure stress.(Safe Work Australia, 2009) This phenomenon might be explained given that claims arising from traumatic incidents are more readily identifiable in terms of medical causation of injury and condition as opposed to the more difficult mental-mental claims which often elicit a range of medical views on causation. Research also indicates that there seems to be little difference in the levels of work stress as between public and private sector workers.(Macklin et al, 2006) Overall this data shows that the costs of stressrelated/mental disorder workers compensation claims are a matter of concern for employers, workers compensation insurers and administrators. However, as will be 
discussed below, the approaches to dealing with these issues is fraught. In 1996 Dollard and Winefield observed that;

[t]he politics involved in conceptualising the stress problem and in recognizing psychological disorder as a leading occupational health issue in Australia has impaired advances towards prevention and treatment and the status of occupational stress as a national policy issue. (Dollard \& Winefield, 1996)

A review of occupational stress interventions in Australia in 2004 by Caulfield et al found that overall the focus in Australia had been on individual level intervention and that little data was available on organisational level interventions. Put another way, the research undertaken showed that the emphasis in relation to workplace stress had been placed on the individual coping mechanisms and strategies.(Caulfield et al, 2004) We argue in this article that in the last two decades legislators have dealt with the 'stress problem' by increasingly reducing the potential for workers to claim compensation for work-related stress conditions. This approach has had a number of consequences. First, compensation litigation has become more complex, expensive and delayed. Second, the costs of stress claims have not been reduced by the legislative intervention. The current legislative provisions focus on excluding stress claims thereby providing few incentives for employers to implement organisational stress management interventions. Third, the increasing exclusion of claims from the workers compensation schemes must in time have some consequences for the general health system. The Heads of Workers Compensation Authorities of Australia (HWCA) has identified that the flow on or cost 
shift of compensation costs to the general health and social security systems seems not to have been investigated in detail to date.(HWCA, 2000) ${ }^{1}$ The Australian Health care system involves a complex interaction between State and Federal governments and allegations of cost-shifting have been constant in recent years.(Buckmaster \& Pratt, 2005).

This article sets out to examine some of the relationships between the policy considerations behind the legislation governing work-related stress claims and how those policies, practices and legislative provisions might impact on the use of health care facilities outside of the compensation system. This article is in four parts. First, it will briefly outline the data on mental health disorders in Australia. This section will also look broadly at the causes of work related stress and mental health disorders. Second it surveys the range of legislative approaches adopted in Australia in related to work-related stress. Third, it provides an analysis of the effectiveness and implications of those interventions upon employers and the broader Australian community. Finally it proposes a corporate citizenship approach that engages all stakeholders in developing proactive alternatives to the prevention and management of stress claims.

\section{Mental Health Disorders in Australia}

\footnotetext{
${ }^{1}$ It is fair to say that the cost-shifting between State and Territory workers compensation and Federal funded social security systems is notorious and well documented. See for example the Preliminary HWCA Submission to the Commonwealth Reference Group on Welfare Reform (28 ${ }^{\text {th }}$ January 2000) at http://www.hwca.org.au/documents/dfacsdraft.pdf (last accessed 13th May 2008). Cost estimates of the effects of shifting the costs of mental disorders from workers compensation to social security are not so far as the authors can discover available.
} 
The starting point for consideration of issues relating to mental health in Australia is the study completed by the Australian Statistician for the Australian Bureau of Statistics in 1997 entitled the Mental Health and Wellbeing: Profile of Adults, Australia (The Health and Wellbeing Report). This study has been the reference point for numerous other contributions to the issue of mental health in Australia. The Health and Wellbeing Report found that almost one in five $(18 \%)$ of Australians had a mental disorder with 12 months of the time of the report data collection. Young adults had the highest levels of mental disorders with the rate of disorder declining with age. Men and women had similar prevalence rates for mental disorders, although women over 35 had higher rates than men, and women were more likely to suffer anxiety related disorders, whilst men were more likely to suffer mental disorders through substance use. Most people surveyed who had an affective disorder met the criteria for depression (women 92\% and men 83\%).(ABS, 1997) The rate of mental disorders was highest among those who lived alone.(Ibid) Significantly, for the purposes of this discussion, the highest rates of mental disorders for men and women were found among those who were unemployed or not in the labour force.(Ibid) Co-morbidity, including physical conditions, is commonly reported among mental disorders.(Ibid) Anxiety and affective disorders generally had a more disabling effect than substance use disorders.(Ibid) The use of health services increases with increased disability, so that those people with combined mental disorders and physical conditions will have increased health care use.(Ibid) In their analysis of the data from the Health and Wellbeing Report, Henderson et al observed approximately half as many Australians have mental disorders as have chronic physical disorders, and that anxiety disorders were the most prevalent form of mental disorder followed by substance 
use and affective disorders. They considered that these rates compared realistically with research from the United Kingdom. The issue of concern for Henderson et al was whether all of the reported cases of mental disorder required treatment. Strikingly, nearly two thirds of the people surveyed who had mental disorders had not sought mental health treatment. Importantly people with a mental disorder accessed general practitioner services about nine times more often than people without mental disorders.(Henderson et al, 2000)

As to the relationship between mental disorder in the community and the level of workrelated stress conditions, some indicative research has been conducted in Australia by Parslow et al who undertook a review of the mental health of a cohort of government workers in the Australian Capital Territory.(Parslow et al, 2004). Their research, consistent with other studies, identified that work-related mental strain and associated psychiatric disorder results from a combination of employment factors which include heavy job demands, limited input to decision making processes, lack of skill discretion with the job and poor work-based social support.(Parslow et al, 2004; Dollard \& Winefield, 2002). Their study took account of a number of factors, but in particular considered the amount of general practitioner health services consumed by workers reporting stressful work environments. The Parslow et al research found that employees working at lower levels reported higher levels of work-related stress; however the research also found that those at lower level positions tended to have better mental health than those at higher level positions, although these findings varied between men and women. Men tended to have poorer mental health at senior positions, whereas women seemed to not be affected by employee level alone. Interestingly, this study also showed 
that men working at lower level positions used fewer general practitioner services than their superiors. Women at middle management levels were less likely to have obtained GP services compared with their senior counterparts.(Parslow et al, 2004) The researchers found that those workers whose job demands were more manageable had significantly better mental health. Men were more adversely affected by lack of skill discretion and women were more adversely affected where job security was compromised. Consequently, women with less job security and who worked longer hours used more general practitioner services. Importantly, the authors concluded that the relationship between work stress and use of general practitioner services was tangible. Given that the Australian Government bears a financial responsibility for a large part of GP service provision through the public healthcare system (known as Medicare), "initiatives aimed at reducing work stress experienced by government employees..." might prove to be a judicious use of Australian Government funding. This study, whilst confined to Australian Government employees does draw an important link between the use of the health system by workers for work-related matters. Whilst it may be that under workers' compensation systems the employer is liable for the costs of ill health arising from work-related stress, there are implications in the Parslow et al study that the Australian Medicare system may also be affected by increases in health services used by workers. This aspect will be discussed in more detail below.

Importantly, a review of strategies designed to reduce occupational stress found that these can be divided into two broad groups; individual level interventions and organisational/individual interface interventions. The former include individual coping strategies which help the individual develop a capacity to build resistance to stress related 
situations. The latter attempt to address the issues of control and power over work which an individual might have and which involve restructuring tasks and workreorganisation.(Dollard \& Winefield, 1996) This divide in intervention strategies provides a useful model for analysing the legislative approaches to work-related stress. Individual level strategies inevitably impact upon health care costs and medical care use usually because such strategies involve higher rates of treatment per worker and may be reflected in workers compensation costs and/or community health care costs. Organisational interventions may be seen as work reorganisation processes. Caulfield et al in their review of occupational stress interventions in Australia found a paucity of research available in relation to organisation interventions, with the available research suggesting that organisational interventions were likely to be more positive than the individual focused interventions.(Caulfield et al, 2004). They posited that the lack of published research on organisational interventions might be due sensitivities surrounding such research, that is, the exploration of work stress within an organisation might provoke an increase in claims or alternatively the publication of a successful strategy might give the opposition a competitive edge.(Ibid) From a legislative point of view, organisational interventions are most commonly evident in Australia in provisions which exclude workers compensation claims arising from management processes. This aspect is discussed below.

\section{Causes of work-related stress and mental health problems}

The foregoing section has briefly outlined the incidence of mental health disorders in the Australia community and some of the issues which arise from this. The following section 
considers the causes of work-related stress. The European Agency for Safety and Health at Work (EASHW) has identified 10 emerging psycho-social risk factors. Emerging in this sense means new and increasing. New refers to a risk which emerges as consequence of new processes, new technologies or social and organisation change in the workplace. Increasing is a reference to a rise in the number of hazards contributing to the risk, the likelihood of exposure to those hazards rising or the effects upon worker health worsening. These emerging risk factors include;

1. Precarious contracts in the context of unstable labour markets

2. Increased worker vulnerability due to globalisation

3. New forms of employment contracts

4. Feelings of Job insecurity

5. Ageing workforce issues

6. Long working hours

7. Work intensification

8. Lean production and outsourcing

9. High emotional demands at work

10. Poor work-life balance (EASHW, 2007; EASHW, 2009a, EASHW, 2009b,.Michie, 2002, Williams, 2003))

New forms of employment and job insecurity are usually related to the increase use of short term part-time and casual contracts together with every increasing demands for leaner production.(Lipscomb et al, 2007; Siefert et al, 2007; Clark et al, 2007)) This is often accompanied with outsourcing of work to contractors. The pace of work increases 
and as it does the risk of injury and harm also increases. Likewise as the workforce becomes older workers health and wellbeing is affected where they are not provided with ongoing training and learning opportunities. As consequence the mental and emotional impact upon workers increases often resulting in stress related conditions. Work intensification and restructuring in the form of requirements for workers to handle increasing amounts of information and cope with heavy workloads often leads to feeling of insecurity and is usually associated with closer attention being paid to efficiency and performance.(Quinlan, 2007) As noted below a considerable number of workers cases relate to the issue of performance appraisal and the stress arising from that process. Associated with work intensification is the risk of high emotional demands at work. This might arise from the actual work itself, such as the work of health care providers, police and other social sectors.(Marchand, 2007) In some cases violence and bullying at work can also add a further dimension to work place pressures and frequently result in stress related conditions affecting mental health.(Mayhew \& Chappel, 2007; Saunders et al , 2007; Bourbonnais et al, 2007)) Overlaid with the issues arising out of bullying, which are substantial, are the effects of downsizing and workforce reductions.(Lee, 2000, Zapf, 1999; Danna \& Griffin, 1999; Greenberg, 2004) Finally, work-life balance or imbalance is also associated with poor mental health where the demands of work arising from precarious employment and work intensification in particular lead to conflict between the demands of work and private life.(Oomens et al, 2007) Importantly, consistent with Australian data, Lippel has observed that access to compensation for psychological disability related to stress is more difficult for women than for men, so that gender is an additional issue in relation to mental health of workers.(Lippel, 1999). Further in the 
course of her analysis of literature she identified a range of stressors which contribute to work-related stress claims. These factors include lack of social support and recognition, role conflict ambiguity and job changes, high workforce turnover, heavy responsibilities, conflictual relations, overwork, negative evaluation, lack of training and control.(Ibid). Consistent with these themes is the assertion by Greenberg that '...sound scientific evidence has shown that people who believe they have been treated unfairly on their jobs experience considerable distress. Feelings of distress-especially when chronic in occurrence and extreme in magnitude- have been linked to a wide range of adverse medical conditions.'(Greenberg, 2004). It follows that the causes of workplace stress are multi factorial but usually consist of a blend work intensification issues which coincide with interpersonal challenges, which if not properly managed, may lead to dysfunction at both a personal and organisation level. The nexus between the organisational and interpersonal present both management and legislative challenges. At a management level the challenges relate to performance management, prevention of workplace bullying and suitable workplace change management. Those issues are beyond the scope of this article, however, the legislative responses to workplace stress are explored below.

\section{Legislative requirements for work-related stress conditions}

As noted in the introduction, claims for injury, disease or disability caused or contributed to by stress at work are costly and time consuming.(Medibank Private, 2008) Australian State and Territory governments have attempted to reduce these costs, usually by legislating to exclude stress related claims. Specifically, where the worker's injury, disease or disability arises in circumstances involving the exercise of reasonable 
administrative, disciplinary or related powers by the employer and also by increasing the threshold work contribution requirement for work-related disease. Up until the 1980's most State and Territory workers' compensation schemes provided that in the case of gradual onset conditions, the work element required to make a compensable claim was simply that the work was a recognisable feature in the condition. In the mid 1990's these thresholds were raised, requiring the work contribution to be either significant or material or substantial depending on the level of workplace input which the State or Territory parliament desired.

In Australia, as in most jurisdictions which retain workers' compensation schemes such as Canada and United States, workers' compensation claims are broadly divided into two groups: Claims for injury or for disease related conditions. Personal injury arising out of, or in the course of, employment is a legislative requirement typical in all Australian jurisdictions. The Australian courts have established that a wide scope of activities may be regarded as 'arising out of' or 'in the course of employment'. Such activities include the worker doing something reasonably required by the employer even it were not their normal duties (Kavanagh v Commonwealth (1960) 103 CLR 547) and even if the injury occurred in an interval between active work, and intervals or interludes which occurred in the course of employment where the employer had induced, or encouraged, the employee to spend that interval or interlude at a particular place or in a particular way.(Hatzimandis $v$ ANI Corp Ltd (1992) 173 CLR 473) This judicial approach differs from the more restrictive approaches taken in Canada and United States which as a general rule require some evidence of the injury being connected with work activity. 
A claim relating to a mental disorder or stress may arise either by an injury or disease. In the case of injury claims it is necessary to show the event lead to a sudden physiological change in the worker, but as indicated above, it is not necessary to show that the event occurred whilst the worker was actually working. This usually requires proof that the medical condition arose out of a specific event that is usually traumatic in nature, such as physical assaults, bank robbery, train accidents or witnessing these events. With regard to disease, these are compensable in specific circumstances which are discussed below.

\section{Workers Compensation for disease based conditions}

The definition of disease is similar under most Australian compensation schemes. For example, disease is defined under the Workers Compensation and Injury Management Act 1981 (Western Australia) as "any physical or mental ailment, disorder, defect, or morbid condition whether of sudden or gradual development". This form of words also appears in the Safety Rehabilitation and Compensation Act 1988 (Cth) and most other State and Territory provisions. In Comcare v Mooi, (1996) 137 ALR 690 a decision dealing with the Safety Rehabilitation and Compensation Act 1988 (Cth), the issue of a disease/ailment was considered. It was held that if a worker was to claim compensation for a stress related disease, they must prove that their "...condition...is outside the boundaries of normal mental functioning and behaviour." This early decision set a reasonably low threshold for claimants, but as will be discussed below, this threshold has been subject to a range of legislative interventions. 
Conditions contracted by a gradual onset or process will not normally fall within the definition of injury.(Roberts v Dorothea Slate Quarries Co Ltd [1948] 2 All ER 201 and MGH Plastic Industries Pty Ltd v Zickar (1996) 186 CLR 310) As noted, there is a need to show, at a minimum, some specific identifiable trauma; albeit in some cases, of a minute character.( State Energy Commission v Van-Zyl (unreported, SC(WA), SCL4879, 27 April 1983) In order for a disease to be compensable, there must be an employment contribution to the development of the condition. This is in marked contrast to the situation where the claim is made for an injury. As shown above, such a claim may be compensable even if there is no active work contribution but the activity falls within the scope of the employment because the worker happened to be at work when the event occurred.

The level of employment contribution required in the case of a disease claim under the various State and Territory compensation legislation varies, although there are common features. ${ }^{2}$ With the exception of the Commonwealth and Queensland ${ }^{3}$ a disease condition may nevertheless be compensable even though the employment factor is not the only significant cause of the disease and further there may be a number of factors causing the disease some of which may be not work-related.

\footnotetext{
2 In Western Australia, Queensland, Victoria and the Commonwealth, a significant work contribution is required to establish a disease type claim. Whereas, in New South Wales, South Australia, ACT and Tasmania a substantial work contribution is required. Interestingly Tasmania again adopts a more restrictive approach and qualifies its provisions by requiring the substantial work contribution to be the major or most significant factor.

3 In these jurisdictions it has been held that where a work stressor co-exists with a managerial/administrative stressor the claim will be excluded. See Q-Comp v Education Queensland[2005] QIC 46; 176 QGIG 492, Hart v Comcare (2005) 145 FCR 29 Wiegand $v$ Comcare (No. 2) (2007) 94 ALD 154
} 
In most States and Territories a condition recognised as a disease may be compensable under the legislation where there has been an acceleration or aggravation of a preexisting condition. ${ }^{4}$ In relation to stress cases this means that a worker may have a claim for the aggravation or acceleration of a pre-existing stress related condition.

To summarise the above issues; the overall effect of these various disease claim provisions is that stress related claims in Australia are compensable if the applicant can establish the requisite employment contribution. They are compensable notwithstanding that the worker had a pre-existing mental disorder and further the worker is entitled to succeed even where there are other incapacitating conditions so long as the work stress is a significant or substantial contributor to the condition. This formulation for the success of work-related stress claims is perceived by some stakeholders in the compensation system to be too lenient and leaving it open for workers to attach liability, cost and expense to an employer for conditions which are not work-related. As a consequence of concerted pressures in the early 1990's governments in all jurisdictions responded by not only increasing the work contribution thresholds, as noted above, but also by directly excluding claim which arose in certain circumstances. These exclusions have become known as the industrial relations exclusions. Set out below is a discussion of the various common elements of the exclusionary provisions for stress related claims.

\footnotetext{
${ }^{4}$ Acceleration relates to a disease which is progressive in its nature and the aggravation occurs when the rate of progress is increased by some external stimulus. The worker is entitled to claim payments for the resulting incapacity where the acceleration produces some more severe or additional symptoms. Aggravation occurs where external stimuli produces additional symptoms or an intensifying of the existing symptoms which are incapacitating, albeit of a temporary nature, per Federal Broom Co Pty Ltd v Semlitch (1964) 110 CLR 626
} 


\section{Discipline, Disciplinary and Administrative Action by the Employer}

The Commonwealth, New South Wales, Victoria, Western Australia and ACT have similar legislative provisions which limit the scope of stress claims where the stress arises out of various management and industrial relations issues. The Commonwealth, in particular, precludes compensation where the stress arises out of reasonable disciplinary action. South Australia, Northern Territory and Tasmania however, have provisions that exclude compensation for reasonable administrative action. Queensland provisions refer to reasonable management action.

\section{Disciplinary Action}

In Re Rizkallah v Australian Postal Corporation (1991) 23 ALD 572 the question arose as to whether or not an employee who had received counseling in her workplace due to her poor work performance and as a consequence developed an anxiety disorder had been subject to reasonable disciplinary action. It was held that disciplinary action was an action that contained "all aspects of the system of rules for the conduct of employees and enforcement of those rules by any means." In a very detailed analysis of these provisions in Comcare $v$ Chenhall(1992) 109 ALR 361 Cooper J noted that disciplinary action included only the action itself, not the steps which lead to the decision of such disciplinary action. This was considered to be a fairly narrow interpretation. This view was also adopted in Re Quarry v Comcare (1997) 47 ALD 113 and Arthur v Comcare [2004] AATA 241 where, in both cases it was held that counselling sessions did not form part of the disciplinary action. However, in Re Choo v Comare (1995) 39 ALD 399 
which dealt with the same legislation it was held such sessions did constitute part of disciplinary action. The effect of this exclusion is that if the workers condition arises from stress caused through reasonable disciplinary action the claim will be excluded. Similar outcome result from the following exclusions discussed below.

\section{Performance Appraisal}

New South Wales, the Commonwealth and ACT specifically refer to performance appraisal as being a ground for excluding a stress claim. In South Australia, Northern Territory, Tasmania and Queensland a performance appraisal could be included as reasonable administrative or management action and would therefore fall outside the exclusions. As noted the South Australian and Tasmanian exclusion provisions in relation to stress refer to reasonable administrative action by the employer as being action which excludes a stress claim should the condition arise from that action. This exclusion has broader application than the concepts of disciplinary action or discipline. This limitation was applied in Department of Education v F [2004] TASWRCT 43 where it was held that mere allocation of workload constitutes an administrative matter and any stress arising out of that action would not give rise to a claim in those States which have these exclusions.

Stress arising from performance appraisal will exclude a claim in New South Wales, ACT, South Australia, Northern Territory, Tasmania the Commonwealth and Queensland. These jurisdictions have set the bar considerably higher than Western Australia and Victoria. However, it is notable that stress arising from mere performance 
of duties, (even if subject to correction and direction from time to time) and workload issues would normally be considered as unaffected by the exclusions applying to stress claims. As indicated above, a claim may still be compensable even if the stress is caused by administrative action, disciplinary action or discipline provided that the worker can show that another non-excluded stressor was evident and the stress not due to wholly or predominantly administrative action, disciplinary action or discipline.

\section{Unreasonable and Harsh Behaviour on the part of the Employer}

Even where it is established that the stress is related to the discipline, disciplinary or administrative action of the employer the worker may succeed with a stress claim where the behaviour of the employer is regarded as unreasonable. In Catholic Care $v$ Wrafter, (unreported, CM (WA), 60/96, 28 October 1996) it was held that the manner in which a disciplinary meeting was held was unreasonable and harsh, therefore resulting in the worker suffering stress. This decision was followed in other cases. (Housing Industry Assoc v Murten (unreported, CM (WA), 231/01, 26 November 2002) confirmed on appeal in Housing Industry Assoc Ltd v Murten [2004] WASCA 139) In Department of Education \& Training v Sinclair [2004] NSW WCC 90 it was held that action by the employer to totally prohibit contact by the respondent/worker with students of a school and failure to provide details of the allegations it was investigating was unreasonable. ${ }^{5}$

\footnotetext{
5 Sinclair's case attracted considerable attention as he had been dismissed from teaching due to allegations of sexual misconduct with a student. See 'Affair teacher's compo to spark law change.' Sydney Morning $\quad$ Herald $\quad 5 \quad$ April 2005

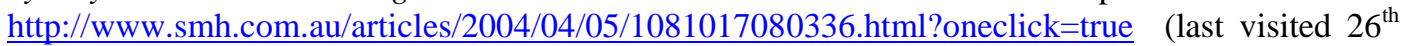
April 2006)
} 
This decision was overturned on appeal on the basis that in determining whether the employer's actions were unreasonable it was necessary to take into account the overall process rather than to focus on a particular "blemish" in the process. (Department of Education \& Training v Sinclair [2005] NSWCA 465 at para 97) In Mitsubishi Motors Australia v Lupul [2004] SAWCT 130 it was held that reasonableness must be considered in the light of certain factors, for example, the workers history, age, personality and legitimate expectations.

A number of Commonwealth cases also illustrate various aspects of the requirements needed to establish unreasonable disciplinary action by an employer. In Dimitriou $v$ Australian Postal Corporation(unreported, AAT, No V91/383, 14 January 1993) the tribunal found that what constitutes reasonable disciplinary action would depend upon the nature of the employee's duties, the worker's conduct and the laws governing the worker's duties. In Re Bartlett v Comcare(1996) 40 ALD 709 an employee who was suspended from her duties as a result of browsing confidential information but who was not given a chance to respond to allegations of misconduct was awarded compensation as it was held that her employer has acted unreasonably. A similar outcome occurred in Asker $v$ WorkCover Corporation[2004] SAWCT 115 where an employer's action were seen as unreasonable where it dismissed a worker for participating in industrial action when the worker denied this and was subsequently proven correct. (See also Rukavina v Bridgestone Australia Ltd [2005] SAWCT 79). Even if disciplinary action is appropriate the employer must be still be careful not to impose an excessive penalty as this may be regarded as unreasonable behaviour and provide an avenue for entitlement for the worker.(Delongville v South Australia Police [2004] SAWCT 31) 


\section{Reasonable Discipline, Disciplinary and Administrative Action by an Employer}

The discipline, disciplinary or administrative action taken by the employer in dealing with an employee may be regarded as reasonable; so that if it is established that the stress is predominantly related to such action the workers claim will fail. The employer's disciplinary actions will usually be reasonable where there are allegations of criminal conduct by the worker, for example, a worker failing to disclose pre-employment convictions (Fernandez v South Australia (unreported, SC (SA), No. SCGRG 93/1558, 28 July 1994) and deceitful (Delongville v South Australia Police [2004] SAWCT 31, and fraudulent behaviour.( Pawluk v WorkCover [2004] SAWCT 85)

Where no charges have been laid, but allegations are serious, the employer needs to proceed with more care. The requisite level of care (which will vary according to the circumstances) was satisfied in numerous cases, for example, a teacher receiving a number of formal warnings and meeting over serious allegations, (Abrahams $v$ St Virgil's College (unreported, SC(Tas), Underwood, J, 53/1998, 11 May 1998) an employer organising several meetings to allow a worker the opportunity to answer allegations of misconduct (Boyd v WorkCover [2004] SAWCT 76 ) and an employer holding discussions with a teacher over inappropriate behaviour towards students (Kershaw $v$ Department of Employment, Training and Further Education [2003] SAWCT ). In all the above situations, it was found by the courts that the employers had taken reasonable disciplinary action because the worker had been given the opportunity to answer allegations and consider their conduct. As noted above there are number of other specific 
exclusions which apply to prevent a worker proceeding with a compensation claim, these generally include (in most jurisdictions) stress related conditions arising from transfer, (Jenkins $v$ Western Australian Department of Training [1999] WASCA 199) redeployment or redundancy (Levi v Unisure Pty Ltd (University of Adelaide [2000] SASC 167) or failure to obtain promotion (Re Awad v Comcare (1996) 45 ALD 400) or failure to be awarded any other benefits.(Re Frank v Comcare (1996) 41 ALD 597, Golds v Comcare [1999] FCA 1481, Trewin v Comcare (1998) 84 FCR 171 ) It is not necessary to traverse all of these exclusions, suffice to say that the worker who makes a compensation claim in circumstances where the employer raises the defence of one or more of these matters the worker is really put to proof in relation to the causation of there stress related condition. These exclusions require a close examination of the conduct of the worker and employer and in many respects mimic the kind of investigation familiar to those involved in industrial relations litigation. The litigation of these cases often points to breakdowns in organisation change management structures and frequently to poor interpersonal interactions. A related issue which space does not permit a detailed examination of is the question of prevention. All Australian jurisdictions have occupational health and safety (OHS) laws which enable inspectors to enter a workplace to review or investigate workplace hazards. The detection of workplace stressors such as workload pressures or bullying may implicate OHS action. In Australia prosecutions for bullying and stress related hazards are notorious difficult because of the criminal standard of proof required to prosecute. (Work Safe Victoria, 2009) Only the Occupational Health, Safety and Welfare Act 1986 (SA) and Occupational Health and Safety Act 2000 (NSW) have specific provisions which address workplace bullying as a hazard. 


\section{The Commonwealth's Position Since 2006}

The Australian Safety and Compensation Council (now known as Safe Work Australia) commissioned a survey of the respective exclusion provision in Australian workers compensation legislation entitled Australian Workers' Compensation Law and it Application - Psychological Injury Claims (the Pearce Report). The Pearce Report concluded that the stress exclusion provisions in each jurisdiction were largely homogenous and whilst there were some semantic differences in the threshold work contribution tests, that these differences were not substantial. Three important points were made in the Pearce Report. First, as at November 2006, the Safety Rehabilitation and Compensation Act 1988 (Cth), did not allow exclusion of claims based on reasonable administrative action. Second, amendments should be made to the Safety Rehabilitation and Compensation Act 1988 (Cth), to align it with other jurisdictions and finally the authors noted that “...great benefits might be obtained through attempts at prevention and early rehabilitation of psychological injuries.'(ASCC, 2006) The latter conclusion is however arrived at without any statistical analysis and it is hard to see how the authors have come to this view other than by the implied observation that the current exclusion provisions simply establish a myriad of complexities through which a worker must proceed in order to obtain income support.

In 2006 the Commonwealth Parliament amended the Safety Rehabilitation and Compensation Act 1988 (Cth), to further strengthen the exclusion provisions under that Act. The amendments removed the uncertainties, which had arisen by reason of the 
inconsistent judicial approaches shown in some of the cases dealing with whether counselling and performance appraisal were included in the disciplinary action taken by the employer noted in the commentary above. In addition, up until 2006 the Safety Rehabilitation and Compensation Act 1988 (Cth), required that only a material work contribution was necessary to activate a claim for a compensable stress related condition. This threshold has now been increased to require a significant degree of work contribution to the compensable stress related condition and this term has been defined to mean a degree that is substantially more than material. In addition, prior to 2006 the Safety Rehabilitation and Compensation Act 1988 (Cth), exclusions were similar to the Western Australian and Victorian provisions which focus on the employer taking reasonable disciplinary and related action. Since 2006 the exclusion provisions provide as follows;

\section{(1) [A claim for a disease based stress related condition can be made ]}

but does not include a disease, injury or aggravation suffered as a result of reasonable administrative action taken in a reasonable manner in respect of the employee's employment.

(2) For the purposes of subsection (1) and without limiting that subsection, reasonable administrative action is taken to include the following:

(a) a reasonable appraisal of the employee's performance;

(b) a reasonable counselling action (whether formal or informal) taken in respect of the employee's employment; 
(c) a reasonable suspension action in respect of the employee's employment;

(d) a reasonable disciplinary action (whether formal or informal) taken in respect of the employee's employment;

(e) anything reasonable done in connection with an action mentioned in paragraph (a), (b), (c) or (d);

(f) anything reasonable done in connection with the employee's failure to obtain a promotion, reclassification, transfer or benefit, or to retain a benefit, in connection with his or her employment.

"disease" means:

(a) an ailment suffered by an employee; or

(b) an aggravation of such an ailment;

that was contributed to, to a significant degree, by the employee's employment by the Commonwealth or a licensee.

"significant degree" means a degree that is substantially more than material.

As can be seen from these provisions, the Safety Rehabilitation and Compensation Act 1988 (Cth) has amalgamated all the of the exclusion provisions which have been applied in other jurisdictions. This approach broadens the scope of the exclusion clause. In addition, the threshold of significant degree of contribution has been clarified so that save 
for Tasmania, this threshold is probably the most stringent in Australia. We argue that in effect because the Safety Rehabilitation and Compensation Act 1988 (Cth) now includes the combination of a higher threshold and more extensive exclusions these provision are the most extensive exclusion clauses in the Australian legislative landscape.(Tomaras \& Nielson, 2007)

There are two issues which arise from this change. First, since the High Court decision in Attorney-General (Victoria) v Andrews [2007] HCA 9 the Commonwealth Government is now free to license multi-state employers to exit the State and Territory workers' compensation systems and operate under the Safety Rehabilitation and Compensation Act 1988 (Cth) (known as Comcare). This migration has arisen out of a demand by multistate employers to reduce their compliance costs for workers compensation and occupational health and safety. By granting licenses to large multi-state employers to move to Comcare, large numbers of workers have now migrated into coverage under the Safety Rehabilitation and Compensation Act 1988 (Cth). Thus, by reason of the decision in Attorney-General (Victoria) v Andrews, more workers are now covered under Comcare than ever before and the numbers are likely to rise as more employers choose this course. As a consequence, growing numbers of workers will be required to comply with the stress exclusion provisions outlined above. In short, growing numbers of workers will find it hard to make compensable stress related workers compensation claims in Australia.

Second, there is a tendency in nations with multiple State and Territory jurisdictions such as Australia, Canada and the United States, for there to be high levels of comparison and to some extent 'templating' of provisions considered to be transferable across borders. 
Perhaps the nest example of this in Australia has been the development of the stress claim exclusion clauses that had their genesis in Victoria and were later refined and included in all other jurisdictions (as shown in Table 1). The adoption of the Commonwealth template for stress claim exclusions is therefore likely to be adopted in many jurisdictions especially Victoria and South Australia where there is an indication of increasing levels of stress claims (cf Figures 1 and 2 ). As a consequence the importance of the changes to the Safety Rehabilitation and Compensation Act 1988 (Cth) cannot be overstated and represent a continuing trend in attempts to restrict compensable stress related claims.

\section{The Effectiveness of Exclusion Provisions}

As noted earlier in this article, compensable stress related claims are the most expensive form of compensation claim in almost every Australian jurisdiction. To combat the rising costs, each State and Territory has implemented legislative amendments to reduce the number of compensable stress related claims lodged by workers. In order to assess whether such provisions have been successful, it is essential to analyse statistical data from each jurisdiction, highlighting when amendments were implemented in each State and Territory and whether the subsequent number of claims were reduced or stabilised. Table 1 shows when the respective legislative amendments to include stress claim exclusions were introduced in each jurisdiction.

\section{TABLE 1}

\begin{tabular}{|l|l|}
\hline Jurisdiction & $\begin{array}{l}\text { Year of amendments to include exclusion } \\
\text { provisions }\end{array}$ \\
\hline
\end{tabular}




\begin{tabular}{|l|l|}
\hline Commonwealth & 1988 \\
\hline Victoria & 1992 \\
\hline Western Australia & 1993 \\
\hline South Australia & 1994 \\
\hline Northern Territory & 1994 \\
\hline New South Wales & 1995 \\
\hline ACT & 1997 \\
\hline Queensland & 1997 \\
\hline Tasmania & 2001 \\
\hline Commonwealth & 2006 further amendments \\
\hline
\end{tabular}

Figure 1 below shows the proportion of compensable stress related claims among the overall workers' compensation claims in each State and Territory. These proportions include both lost-time and no lost-time claims (lost-time claims indicate claims where the worker was absent from employment for one work shift or more and no lost-time claims indicate claims where the worker was not absent from employment). Figure 2 highlights the proportion of lost-time stress related claims as against lost-time workers compensation claims in general. ${ }^{6}$

\footnotetext{
${ }^{6}$ It is important to highlight several issues before an analysis of this data is undertaken. For example, the availability of statistical data to the public in several jurisdictions was, at the time of writing, very limited. Other issues were also bought to light, for example, different jurisdictions collate and present data in different modes, which in turn, increased the difficulty in accurately comparing one jurisdiction to another. During the compilation of data, it became evident that stress related statistics were not as readily available as first thought. Although all jurisdictions provided statistical reports, many however did not provide sufficient detail. For example, general stress related data was provided, such as the overall total of claims lodged within each financial year, however, this data was often apportioned into lost-time and no lost-time figures. This posed a significant problem. Although it was useful to have general statistical stress related data, it was also vital to know the total number of lost-time stress related claims in order to understand whether a workers' stress related condition may be so severe that it warranted their absence from work. Additionally, many statistical reports only provided current statistics and did not extend to past statistical years. This too, posed a significant problem. In order to effectively analyse the effect of legislative amendments upon stress related claims, it was necessary to observe statistical data before the amendments were implemented and after they were implemented.

A major difficulty in comparing data was the manner in which each State and Territory compiled and presented information. Each jurisdiction presented data in different modes. For example, West Australian
} 
statistical reports present stress related claims in lost-time figures only, whereas the Commonwealth, New South Wales and Queensland present data in lost-time and no lost-time combined figures. There was also a variation in the category in which a stress related claim was presented. For example, the Commonwealth presented data on the number of claims accepted by Comcare per financial year, several States and Territories based their data on which financial year the stress claim was received by WorkCover, while the remainder based their data on the financial year in which the injury occurred. This again made it difficult to compare one jurisdiction's data with others.

There was also a difference in relation to the type of stress claim which was presented in the reports For example, some jurisdictions based their data on the mechanism of injury, while the others present data on the nature of injury. One jurisdiction (South Australia) also compiled their statistics by separately analysing the data from exempt employers (self-insured employers who manage their own claim) and non-exempt employers (those who are insured by WorkCover). This jurisdiction only provided selected statistics in both exempt and non-exempt mode, and favoured presenting the majority of data in non-exempt mode. Such a mode was not evident in any other jurisdiction. The data for this article was collected from the following sources;

H Karimi WorkCover WA 2006, pers. comm., 19 Sept 2007,. H Karimi WorkCover WA 2007, pers. comm., 2 Januaryy2007.,J Dertilis WorkCover SA 2001, pers. comm., 31 January., B Hasler WorkCover ACT, 2007, pers. comm., 2 February 2007, Victorian WorkCover Authority, 2004-2005 Statistical Summary WorkCover NSW, Statistical Bulletin 1999/2000, WorkCover NSW, Statistical Bulletin 2000/2001, WorkCover NSW, Statistical Bulletin 2001/2002, WorkCover NSW, Statistical Bulletin 2002/2003, WorkCover NSW, Statistical Bulletin 2004/2005 U Sreedharan Q-COMP 2007, pers. comm., 19 January 2007, WorkCover QLD Annual Reports 1996/1997, 1997/1998, 1998/1999, WorkCover Queensland Scheme Statistics 1999/2000, WorkCover Queensland Scheme Statistics 2000/2001, WorkCover Queensland Scheme Statistics 2001/2002, WorkCover Queensland Scheme Statistics 2002/2003, WorkCover Queensland Scheme Statistics 2003/2004, WorkCover Queensland Scheme Statistics 2004/2005, WorkCover Queensland Scheme Statistics 2005/2006, K Horwood NT Worksafe 2007, pers. comm.., 22 January, L Khull Workplace Standards Tasmania 2007, pers. comm.., 14 February 2007 , Years 1995/96 - 1999/2000 based on new claims received by Comcare. Years 2002/03 - 2005/06 based on nature of injury claims accepted by Comcare., New Claims Received by Comcare: Safety, Rehabilitation and Compensation and Other Legislation Amendment Bill 2000, 2000-2001 Bills Digest No.11. Last viewed March 19, 2007, from http://www.aph.gov.au/library/Pubs/bd/2000-01/01BD111.htm., Comcare 2003, Comcare Annual Report 2002-2003, p.16. Last viewed March 20, 2007, from www.comcare.gov.au/_data/assets/pdf file/1021/Comcare AR-2002-03.pdf. Comcare 2004, Comcare Annual Report 2003-2004. Last viewed March 20, 2007, from http://www.comcare.gov.au/publications/general/comcare_annual_report_2003-

2004/performance snapshot, Comcare 2005, Coтcare Annual Report 2004-2005. Last viewed March 20, 2007, from http://www.comcare.gov.au/publications/general/comcare annual report 2004 2005/performance snapshot, Comcare 2006, Comcare Annual Report 2005-2006, p. 24. Last viewed March 20, 2007, from http://www.comcare.gov.au/_data/assets/pdf_file/24458/Comcare_Annual_report_05-06.pdf, WorkCover Western Australia 2007, Number of Work-Related Stress by Year Claim Lodged., WorkCover Corporation South Australia 2007, Statistics., ACT WorkCover 2007, All Claims - Group 10 Mental Disorders (Nature of Injury), Victorian WorkCover Authority n.d. 2004-2005 Statistical Summary, pg. 16. Last viewed March 20, 2007, from http://www.worksafe.vic.gov.au/wps/wcm/resources/file/ebcca6435d4cc68/statistical_summary.pdf.Victori an WorkCover Authority 2007, Standardised Claims WorkCover New South Wales 2004, Statistical Bulletin 2001/02, pp. 29 \& 64. Last viewed March 20, 2007, from http://www.workcover.nsw.gov.au/NR/rdonlyres/4BBA1D7E-F34E-4D6E-81F915F6FB3AD4C0/0/statistical_bulletin_01_02_520_4.pdf , WorkCover New South Wales 2005, Statistical Bulletin 2002/03, pp. 29 \& 70. Last viewed March 20, 2007, from http://www.workcover.nsw.gov.au/NR/rdonlyres/9AAAB281-77F9-48A3-8664991CB0CEFD46/0/statistical_bulletin_02_03 520_5.pdf , WorkCover New South Wales 2005, Statistical Bulletin 2004/05, pp. 43 \& 86. Last viewed March 20, 2007, from 
In Western Australia and South Australia, amendments were implemented in 1993 and 1995 respectively. In both States, it can be seen that the overall number of stress related claims still continued to increase only slightly in the years after the implementation of amendments. There was a slightly different scenario in the ACT, where overall figures fluctuated. Lost-time and no lost-time claims combined appeared to increase initially and then decrease. It is not possible to comment on whether legislative amendments implemented in 1997 in the ACT had any effect on overall compensable stress related figures as data was not available prior to 1999/2000. In Victoria, it can be seen that from $1995 / 1996$ to $2005 / 2006$, the overall number of compensable stress related claims increased gradually from $4.8 \%$ to $8.5 \%$, with the highs proportion of $9.1 \%$ recorded in http://www.workcover.nsw.gov.au/NR/rdonlyres/9AAAB281-77F9-48A3-8664991CB0CEFD46/0/statistical_bulletin_02_03_520_5.pdf , Q-COMP Queensland 2007, Statistics. QCOMP, n.d. Queensland Workers Compensation Scheme 2000-2001 Statutory Claims Analysis, p. 2. Last viewed March 20, from http://www.qcomp.com.au/downloads/corporate/statistics/stats_publication_00_01.pdf ， Q-COMP, n.d. Queensland Workers Compensation Scheme 2001-2002 Statutory Claims Analysis, pp. 2 \& 4. Last viewed March 20, 2007, from http://www.qcomp.com.au/downloads/corporate/statistics/stats_publication_01_02.pdf , Q-COMP, n.d. Queensland Workers Compensation Scheme 2002-2003 Statutory Claims Analysis, pp. 2 \& 4. Last viewed March 20, 2007, from http://www.qcomp.com.au/downloads/corporate/statistics/statistics_report 0203.pdf , Q-COMP, n.d. Queensland Workers Compensation Scheme 2003-2004 Statistics Report, pp. 1 \& 6. Last viewed March 20, from http://www.qcomp.com.au/downloads/corporate/statistics/statistics_report_0304.pdf ， Q-COMP, n.d. Queensland Workers Compensation Scheme 2004-2005 Statistics Report, pp. 6 \& 10. Last viewed March 20, 2007, from http://www.qcomp.com.au/downloads/corporate/statistics/statistics_report 0405.pdf, QCOMP, n.d. Queensland Workers Compensation Scheme 2005-2006 Statistics Report, pp. 5 \& 6. Last viewed March 20, from http://www.qcomp.com.au/downloads/corporate/statistics/statistics_report_0506.pdf Northern Territory Worksafe 2007, Statistics. Workplace Standards Tasmania 2007, Statistics. 
2004/2005. It is difficult to establish whether changes to the Victorian workers compensation legislation in 1992 had any effect on the number of stress claims, as data before 1995 was not available.

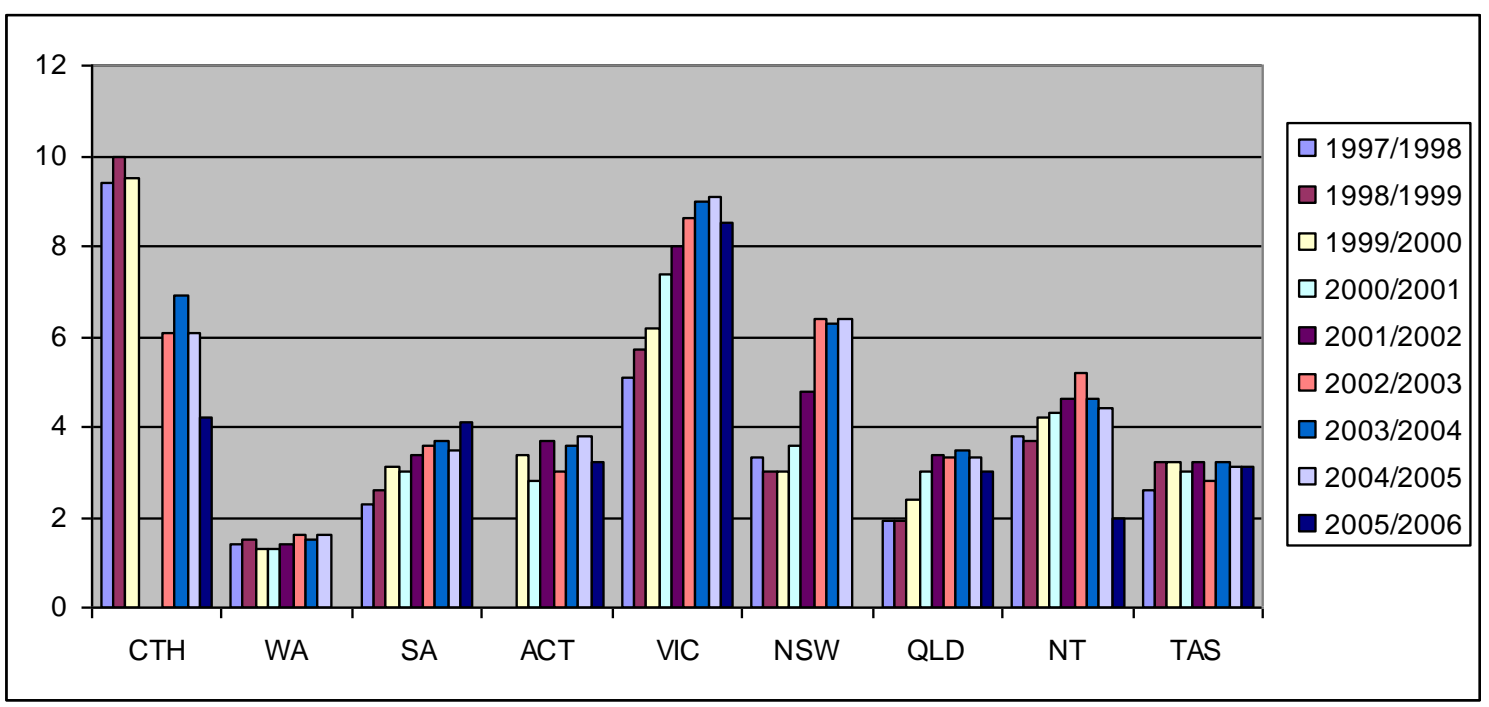

Figure 1. Lost-time compensable stress related claims as a proportion of all lost-time workers' compensation claims in Australian jurisdictions. (Data collected from sources noted in footnote 6 )

In New South Wales, there was an increase in the total number of compensable stress related claims up until 1995/1996, when legislative amendments were implemented. In the financial year of 1996/1997, a year after the amendments, there was a slight reduction in numbers from $2.8 \%$ in $1995 / 1996$ to $2.6 \%$ in $1996 / 1997$. After this period, the total amount of compensable stress related claims dramatically increased, with the greatest percentage recorded in 2004/2005 of 6.4\%. In Queensland, the number of stress claims stabilised at 1.9\% after the amendments were enacted in 1997. However, from 1999/2000 onwards, the percentage began to increase. In Tasmania, after amendments were made in 2001, the overall number of compensable stress related claims increased from 3.0\% in 
$2000 / 2001$ to $3.2 \%$ in $2001 / 2002$, however, slightly reduced in $2002 / 2003$ to $2.8 \%$. This figure increased again in 2003/2004. At the time of writing this article, amendments to the Commonwealth legislation have recently been put in place which will further limit access to compensable stress related claims. It should be noted, however, that the total number of compensable stress related claims accepted and received by Comcare was significantly higher than any other jurisdiction, with the highest percentage recorded in $1995 / 1996$ at $11.8 \%$. This percentage, over time, has gradually reduced, with a lower percentage of $4.2 \%$ recorded in 2005/2006.

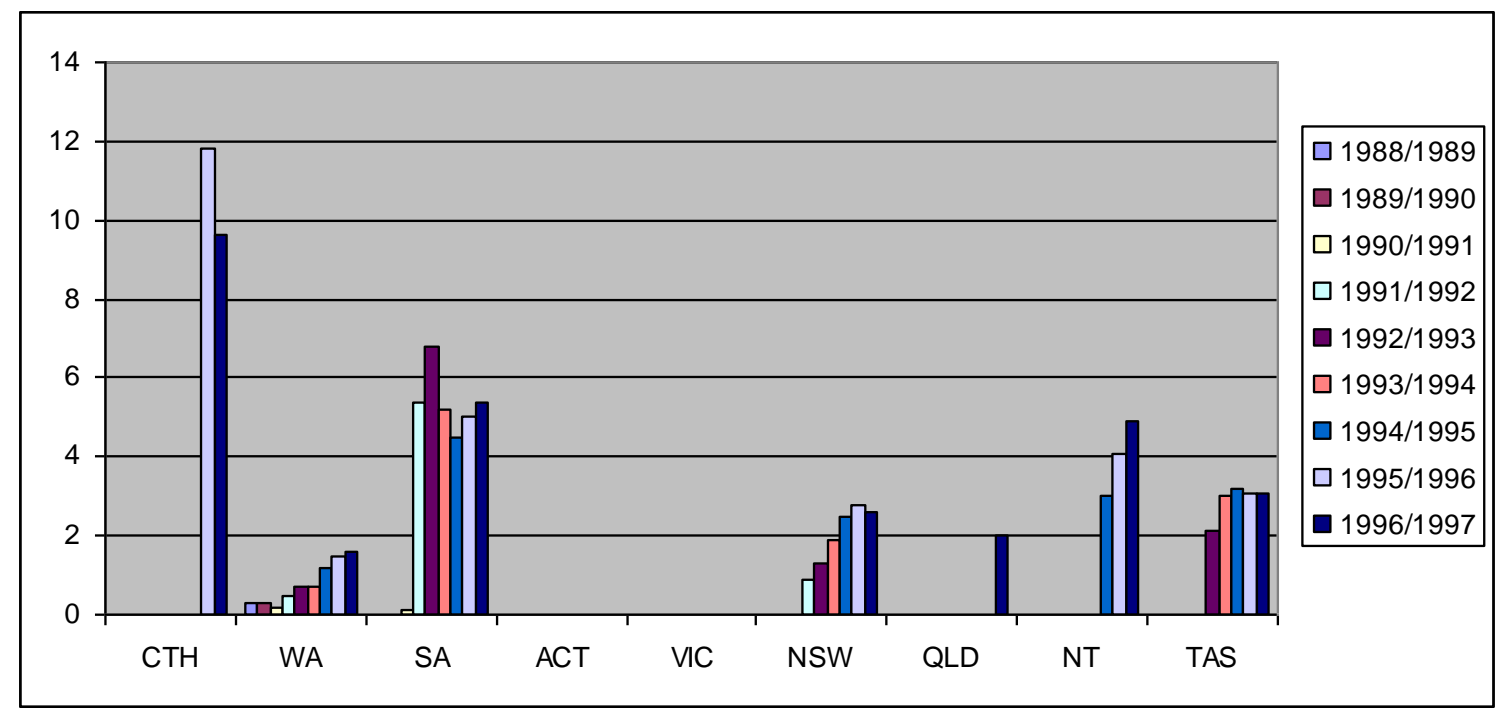

Figure 2. Lost-time claims for work related stress claims. (Data collected from sources noted in footnote 6 ) 


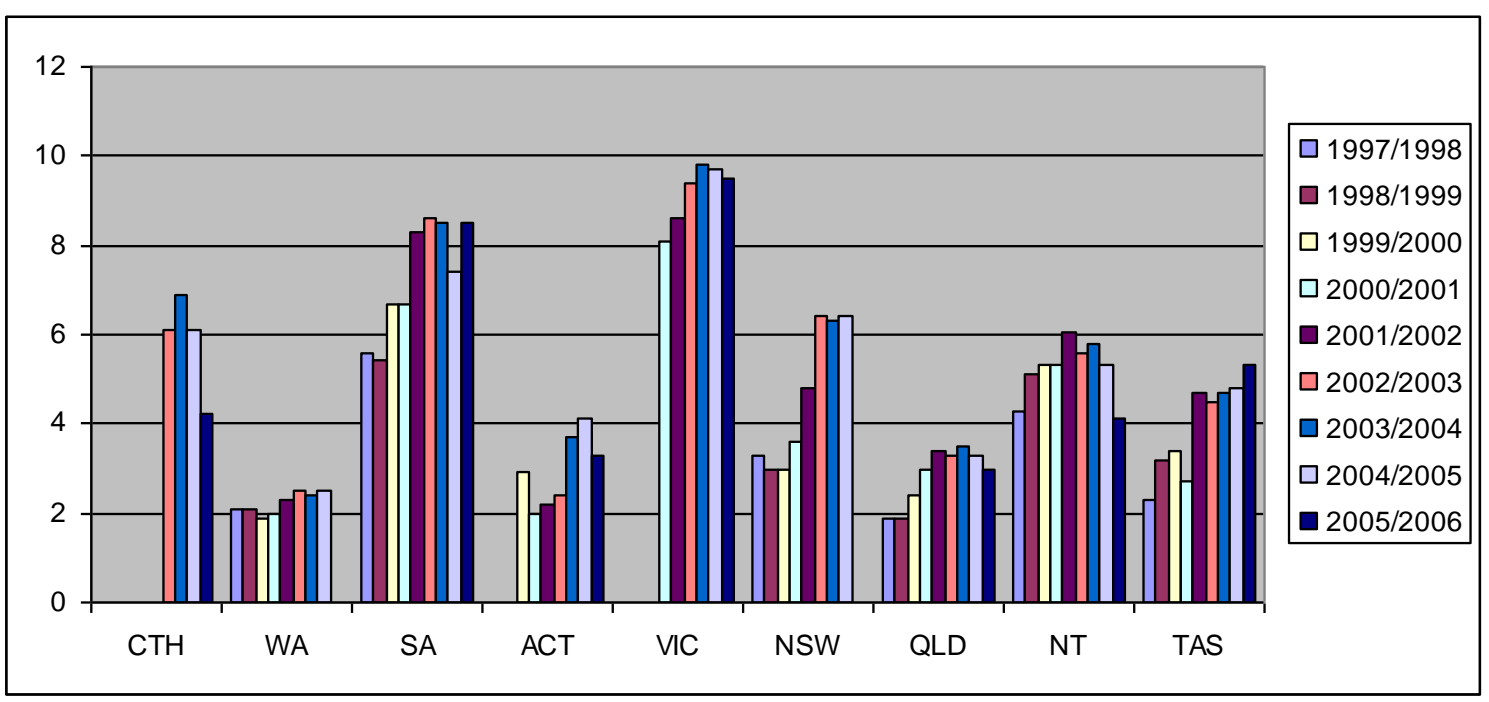

Figure 3 Lost time stress claims as a proportion of all Workers Compensation lost time Claims (Data collected from sources noted in footnote 6)

Figure 3, as already noted, breaks down compensable stress related claims and general workers compensation claims into lost-time only. Generally, in most jurisdictions, a losttime claim is a claim whereby the worker is absent from employment for one day or more. In Western Australia, lost-time compensable stress related claims gradually increased, even after the 1993 amendments were implemented. This was also seen in South Australia. In the ACT, between the years of 1999/2000 to 2003/2004, lost-time figures remained steady, hovering between $2 \%$ to $2.9 \%$. Lost-time figures peaked, however, to $4.1 \%$ in $2004 / 2005$, and then dropped to $3.3 \%$ in $2005 / 2006$. It is impossible to comment on whether legislative amendments implemented in the ACT in 1997 had any effect on lost-time figures, as data was not available before 1999/2000. In Victoria, lost-time compensable stress related claims increased in the years between 2000/2001 to 2005/2006. Again, it is impossible to determine whether or not amendments made to legislation in 1992 had any effect in reducing lost-time compensable stress related claims as such data is not available before 2000/2001. In Tasmania, there was a slight reduction 
in the percentage of lost-time compensable stress related claims in 2000/2001, the same year in which amendments were implemented. However, from 2001/2002 onwards, losttime compensable stress related claims gradually increased. It is not possible to comment on lost-time percentages in the Commonwealth, ACT, Queensland and New South Wales as this information was not available at the time of writing this article.

\section{Trends Evident from Statistical Data}

By analysing the statistical data from each State and Territory as set out in Figure 4 below (which should be read with Table 1 above), it can be seen that compensable stress related claims have been on the rise, regardless of legislative amendments being implemented. The interesting exception to this is the Commonwealth. Although in some jurisdictions, such as Tasmania, New South Wales and Queensland, implementation of amendments has seen a very slight decrease in compensable stress related claims, this reduction trend does not continue for more than two consecutive financial years. This might indicate that the legislative amendments adopted within each jurisdiction have had little effect on reducing the total amount of overall and lost-time compensable stress related claims.

However, it can be argued that in some jurisdictions the amendments have had an effect in stabilising compensable stress related claims. For example, in Western Australia, although the total amount of lost-time compensable stress related claims increased after the 1993 amendments, they did in fact stabilise to $2 \%-2.5 \%$ in the years from 1997/1998 to 2004/2005. Compare this situation to that of other jurisdictions whereby the 
amendments have failed to stabilise the lost-time compensable stress related numbers, for example, South Australia, where from the years between 1990/1991 to 2005/2006, the percentages drastically fluctuated from $0.1 \%$ to $8.6 \%$. In order to test the data collected from each jurisdiction this was compared, so far as possible, with the recent statistical information compiled by Safe Work Australia. There were also gaps in this data set. Figure 4 shows the trend of compensable stress related claims from 1988 to 2005 across all jurisdictions.

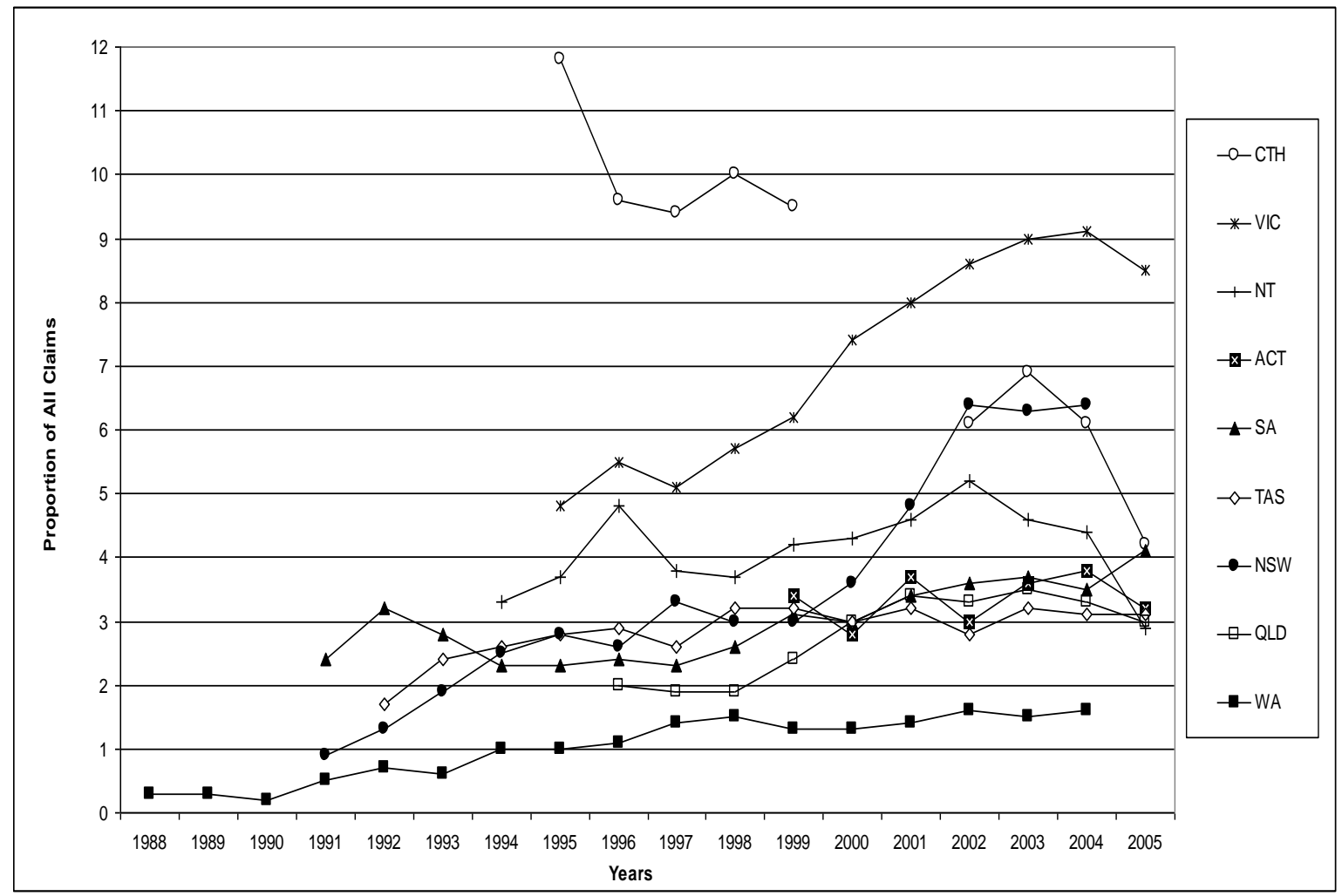

Figure 4 Trends in stress claims across all Australian jurisdictions - Commonwealth Data Collection Safe Work Australia (2006) and Data collected from sources noted in footnote 6 
The rise in compensable stress related claims can be attributed to several causes. It could be argued that legislative amendments to exclude stress claims in each jurisdiction have had little effect. However in the case of the Commonwealth the decline in compensable stress related claims is evident from the data. It is surprising then that the Commonwealth has taken action to further reduce the potential for claims. In other jurisdictions where compensable stress related claims continue to rise this may be due to a number of factors. It is possible to speculate that workers who are employed within industries that have expanded economically at a rapid rate may be subject to highly stressful environments. There may also be a greater awareness of stress in the workplace by workers as a result greater publicity of this issue in recent times. Also, workers may be attributing their stress to other factors which fall outside the scope of legislative exclusions. Additionally there is some evidence that the incidence of workplace bullying is on the increase, or at least the awareness of workplace bullying is growing, leading to an increase in litigation in this respect.(Field, 2003; Einarsen, 1999; Einarsen et al, 2003)) This may also be reflected in claims for workers compensation and also claims in relation to workplace harassment.(AIFS, 2004; ECDGEIRSA, 1998, Wilness et al, 2007))

To return to the original theme as was established in the first part of the article, mental health costs are a significant issue in the Australian health care system. Added to these costs are the associated and perhaps parallel rise in costs and claims for work-related stress. Work stress claims have over time been more difficult to pursue due to a range of exclusion provisions and thresholds which have reduced the scope for such claims. It is possible to speculate on the politics behind the inclusion and continued reliance on stress claims exclusions. First, the introduction of exclusion clauses corresponds with the re- 
election of conservative governments in Victoria, Western Australia and New South Wales. As Table 1 shows other jurisdictions followed the use of the clauses in due course. The strengthening of the provision in the Safety Rehabilitation and Compensation Act 1988 (Cth) also corresponds with the progression of Howard Conservative Coalition Government policies which reinforce managerial prerogatives. This is also evidenced by the introduction of the WorkChoices legislation in 2005, which reduced the role of the Australian Industrial Relations Commission in the settlement of industrial disputes; diminished the powers of Trade Unions and encouraged the use of individual workplace agreements almost entirely free of any statutory minimum provisions. It follows then that the amendments to the Safety Rehabilitation and Compensation Act 1988 (Cth) are part of this broader package of legislation which supports managerial prerogatives. What effect does this have on the health system within Australia? Following this logic, there is an increased likelihood that greater numbers of workers will be covered by the Safety Rehabilitation and Compensation Act 1988 (Cth) and consequently there are potentially greater numbers of workers with mental health conditions who will not be able to claim compensation. If the usual trends in templating continue within the Australian workers' compensation arena, other jurisdictions are likely to adopt the Commonwealth model. In essence this means a greater potential for fewer workers with mental health conditions to be covered by the workers' compensation schemes. These workers may in time turn to the national health scheme for medical care and to the taxpayer funded social security scheme for income support. Therefore, increased research about the shifting of costs out of the workers compensations schemes into taxpayer funded social security and Medicare is needed. It is worth pointing out two 
ironical features of these developments. In the first place, for over a decade the Commonwealth Governments, of whichever political persuasion, have been working assiduously to reduce the potential for workers' compensation costs to be transferred to taxpayer funded social security. This has been achieved, to a high degree, by imposing preclusion periods on workers exiting workers' compensation schemes through settlement of their claims. These preclusion periods prevent a worker with a lump sum settlement from immediately claiming a social security benefit. In effect the period is calculated to correspond with the time it takes for the workers to exhaust the lump sum settlement through the ordinary costs of living.(Industry Commission, 1994) ${ }^{7}$ Second, one of the key impetuses for this leakage is coming from, and in the future will be increased by, the Commonwealth itself. As has been noted, the Commonwealth has historically had notoriously high numbers of stress claimants, but there has been a significant reduction in such claims; this may, in part, be because unlike other systems Comcare statistics reflect the rate of approved claims by Comcare, whereas other systems produce data on raw claim numbers. It is possible that the Commonwealth data collection method still shields a large pool of claims.

\section{Corporate Citizenship: Another approach to the prevention and management of work stress.}

Limiting access to stress claimants through legislative exclusions is a reductionist approach that does not encourage interventions at the organisational level that may

\footnotetext{
${ }^{7}$ The preclusion periods do not apply to stress claimants alone but the fact of a preclusion period and the general difficulties in making claims for work related stress may in fact drive some workers away from the workers compensation system, and force them to claim social security at first instance in preference. For a discussion of cost shifting and social security and health cost see
} 
prevent or reduce the development of stress disorders among workers. As Larsson and Betts have observed 'changing the cost carrier by shifting costs, or excluding certain types of types of injury from compensation, however does not necessarily reduce the size of those costs and consequences'.(Larsson \& Betts, 1996) Rather they serve as a form of claims management by limiting liability and providing some type of protection to employers. However, aiming to simply achieve statutory compliance with legislative provisions has the potential to leave all stakeholders disappointed in the long term outcomes. The increase in the number of stress claims in various jurisdictions following a tightening of the exclusion clauses in the legislation would suggest that employers who seek to only fulfill their statutory obligations with regard to the psychological health and well-being of their employees may not achieve the reduction in stress claims that they may have hoped the legislation would afford them. Workers will continue to develop stress related disorders, and regardless of whether liability for the stress injury is accepted or not by the employer, these stress injuries will eventually impact on workplace productivity through presenteeism and extended employment absenteeism. While the aim of workplace occupational health and safety initiatives is focused on the outcomes of reduced lost time injuries and work absences; prior research has identified that a majority of productivity losses associated with increased health risks among workers, including mental stress, is due to presenteeism; with lesser losses attributed to absenteeism.(Burton et al, 1999) Presenteeism refers to the phenomenon of workers, who report ill health, showing up to work instead of being absent to rest and recuperate.(Aronsson et al 2000) A number of factors contribute to presenteeism, including workplace culture,(Bellaby, 1999) job demands, (Kivimaki, 2005; Aronsson \& Gustafsson, 2005; Demerouti et al, 
2009) and perceived individual choices.(Johansson \& Lunberg, 2004) Workers who experience physical or psychological health distress and who are not granted sick leave (compensable or otherwise), often remain at the workplace leading to an exacerbation of the illness or injury.(Bellaby, 1999) Supporting this notion, a reciprocal relationship between emotional exhaustion and presenteeism has been identified, suggesting that emotional exhaustion leads to presenteeism which leads to further emotional exhaustion.(Demerouti, 2009) Workers experiencing a stress injury may find that they have limited choices in dealing with their health.(Dew et al, 2005) Thus, requirements and exclusions of workers' compensation legislation pertaining to stress-injury claims that limit a worker's access to compensable sick leave can have a powerful influence on promoting presenteeism among injured workers. Whether due to the economic climate or an individual's capacity to find alternative employment, some workers have no option (Ibid) other than to remain in a work environment that is either stressful in of itself, or which does not share the responsibility of promoting a healthy workforce. Therefore, while avoiding the short-term costs associated with a workers' compensation claim, employers may ultimately bear financial losses associated with decreased productivity from injured workers who remain at work, but are less productive.

Given that in all Australian jurisdictions there is a requirement that work is a substantial contributing factor to the development of the stress disorder, the exclusion provisions provide some form of protection for employers against having to deal with stress disorders that were not a direct consequence of work. However, differentiating between work and non-work contributions to mental health conditions is complex in 21st century working life. This is not surprising, given that the risk factors for stress disorders are 
multi-factorial in nature and involve complex interactions between the individual, their task demands and their environment. There is abundant literature reporting factors that contribute to stress,(Kendall et al 2000) in addition to strategies for the prevention and management of work-related stress.(Kendall et al, 2003) Causative and exacerbating factors include personal vulnerability to stress; job demands including excessive workload, and time and performance pressures; and a negative organisational culture including workplace conflict, bullying, violence and harassment and perceived support from the employer. Rapid developments in technology and telecommunications have resulted in a temporal and spatial blurring of when, where and how workers are expected to perform their jobs. As a consequence many white collar workers take work home; the reasons for which vary from real-time telecommunications with business partners operating in other time zones, or simply to work unpaid overtime to complete the demands of the job that are in excess of the paid work week. 'Overspill work' or 'overtime' performed at home in addition to hours worked at the workplace is common among salaried professionals (Pyoria, 2003; Sullivan, 2003) who have a commitment to their work that exceeds their contracted work hours. Likewise, in times of economic prosperity, workers in trade, retail, hospitality and human service professions face increased productivity demands characterised by longer and more frequent shift schedules that may impact on family and home life. Although longer hours of work are frequently associated with self-rated health problems, they are not identified as an independent predictors for health.(Harma, 2003). Shift work is associated with ill health (in particular coronary heart disease) due to changes in lifestyle; most notably a disruption to the circadian rhythm and a discord between social and family 
life.(Knutsson, 2003). The significant relationships between lack of control over the scheduling of shift work and negative effects on family and health outcomes (including lack of work-home balance, burnout, distress and general poor health) (Fenwick \& Tausig, 2001). and the increased risks of psychological distress and sickness absence among workers having the double burden of long work hours coupled with domestic responsibilities(Ala-Mursula et al, 2006),, have been identified. Quite simply, there are high demands on $21^{\text {st }}$ century workers in terms of job performance; time pressures that impact on their capacity and performance in both working and non-working life.

As with many other nations, Australia has developed occupational safety and health $(\mathrm{OS} \& \mathrm{H})$ legislation to promote the health, safety and well-being of workers, while preventing workplace death, injury and disease, including mental stress. (Safe Work Australia). 'However, the 1999 Luxembourg Declaration on Workplace Health Promotion (WHP) in the European Union (EU)(ENWHP, 1997) acknowledged the increasing health impacts of rapid technological and economic changes within workplaces, and advocated for an approach that went beyond traditional OS\&H risk reduction to include health promotion strategies. The Luxembourg Declaration recommended an increased awareness of, and responsibility for, work health promotion among all stakeholders; and suggested the development of a workplace culture and relevant leadership principles whereby employees are actively involved in decision making on issues that affect their health and well-being. The 1998 Tokyo Declaration on Work-Related Stress and Health in three post-industrial settings (EU, Japan and The Unites States of America) reinforced this broad health promotion approach to the prevention and management of work stress. The Tokyo Declaration was based on an "Investment for Health" philosophy, whereby an 
investment of resources in the health of workers will have economic benefits to the organisation and also enhance the health and social capital in and out of the workplace.

These two declarations suggest that as an alternative to traditional (and potentially limited) OS\&H risk reduction strategies, proactive engagement of all stakeholders to address the health and well-being of workers can positively impact on individuals, employers and the wider community. This reflects a corporate citizenship approach to worker health. Corporate citizenship is an overarching philosophy about how business should operate as part of society. Corporate citizenship promotes the integration of the worker and the organisation as partners within the industrial system and as citizens in society.(Drucker, 1946) This approach uses the 'citizen' as a metaphor for assisting organisations to understand the impact of their business-related decisions on the rest of society's citizens, be they human, ecological or other business legal entities. The relationship between business and society began as an economic one, but as public concern grew about the impact of business activity on social and environmental issues, corporations have become increasingly aware of the impact their business activity has on society. Over time, corporate citizenship has grown to include the discretionary behaviour of organisations with regard to community issues broader than just environmental concerns, including the health and well-being of people within the community in which those organisations operate.

Corporate social responsibility (CSR) is one strategy that organisations can implement to generate corporate citizenship. CSR developed through public concern of the effects and influence of corporate actions on society including an organisation's behaviour regarding human rights, labour conditions, health and safety, community involvement, bribery and 
corruption.(Meehan et al, 2006)) However, CSR should be differentiated from corporate philanthropy. While the latter is generosity to the community purely for the purpose of making the organisation look good, CSR identifies and addresses fundamental aspects of environmental and social sustainability which are essential for financial sustainability. While CSR is not another term for 'sustainable development', nor is it 'corporate governance'; good corporate governance will embrace CSR. (Ibid) The expectation is a win-win outcome; for example achieving economic success for the corporation and ongoing financial remuneration, health and well-being for the workers and their families, and reduced financial liability on insurers and the medical and social security institutions. Many large organisations have been required to face their CSR commitments in response to public concern about the effects of their business practices on society; while other enlightened corporations view their CSR as an opportunity to be innovative and secure a competitive advantage.(Porter \& Kramer, 2006)

For CSR to be effective, business and society must understand that they are interdependent, and that instead of short-term activities designed to paint an organisation in a positive light, a long-term commitment to meeting the needs of both the organisation and society are required. There are many case studies of corporations who, through CSR, have achieved financial profitability while addressing the needs of the community. One such example is BHP Billiton's Indonesia Coal Projects.(BHP, 2009) During the exploration and feasibility stages of the project, the organisation conducted a risk assessment in the region on factors that may impact on their future production. Since eighty per cent of their prospective employees were expected to come from the local community, a survey of public health needs was conducted. Among others, it identified 
concerns in the areas of basic hygiene, maternal and child health, communicable disease, clean water, the provision of basic medical services, health service infrastructure and health practitioner training. BHP Billiton is currently working with the local community on programmes to improve the public health of the wider community which will provide its future workers. In this case, the organisation has accepted a joint responsibility to address the needs of the community. This concept of mutuality; that is, engaging with other stakeholders in society to take ownership of a problem or issue, underpins the corporate citizenship philosophy.

With regard to the prevention and management of stress and other mental health disorders among workers, three levels of intervention are described (Lamontagne et al, 2007). Primary interventions are preventative interventions that aim to reduce risk factors for stress at the source; organisational changes to workload, job design and workplace culture may be considered primary interventions. Secondary interventions aim to ameliorate the effects of stress by providing individuals with the skills to cope with, and become resilient to, stressors that are present. Finally, tertiary stress management interventions are those that treat, rehabilitate and compensate workers who are experiencing symptoms of a stress disorder; and include health interventions such as pharmacology and counselling, and workers' compensation and injury management processes. A good corporate citizen would choose to engage in the problem, regardless of liability, because they see it as their mutual responsibility to provide a working environment that minimises stressors and promotes individual psychological health, resilience to stress and overall well-being. Therefore the development of organisational policies and processes to prevent and manage stress work place stress, and the provision 
of a working environment that facilitates coping with work and non-work stressors, is an example of how an organisation can move beyond the minimalist legal requirements of OS\&H legislation. Such organisational interventions that are driven by economic value, moral, ethical and even discretionary motivations are regarded as good corporate citizenship, when these organisational practices become part of the culture of the workplace.(Carroll, 1979) The overall result is improved worker health and well-being and economic gains for the organisation.

A review of stress management interventions have identified interventions that occur at the organisational level (i.e. primary interventions), are likely to be more successful and have longer term benefits to both the individual and to the organisation, than (tertiary) interventions aimed only at the individual level.(Lamontagne et al, 2007) Organisational level interventions that prevent or minimise the impact of work-related stress are beneficial to all stakeholders. Porter and Kramer (2006) state;

The more closely tied a social issue is to the company's business, the greater opportunity to leverage the firm's resources and capabilities, and benefit society.(Ibid)

These organisational strategies include a variety of human resources management practices such as communicating with workers to monitor stress levels and needs; collaborative workplace and task re-design; empowering workers through participatory management and the development of organisational policies and processes that are family-oriented and socially supportive, to assist workers in becoming resilient to stress.(Kenny, 1995; Goddard, 2004). However, there appears to be a disconnect between 
preventative primary and secondary strategies and tertiary (rehabilitation and compensation) strategies.( Lamontagne et al, 2007)

In the event that a worker develops a work-related injury, illness or disease; workers' compensation legislation is designed to minimise the social and economic impact of injury and disease on workers, and achieve cost effectiveness for employers and the community.(WorCover WA) Workers' compensation legislation that provides incentives to employers to implement proactive organisational stress prevention and management interventions can help promote a CSR approach. For example, legislative requirements for the introduction of organisational injury management policies and processes can facilitate a cost-effective return to work for the employee. Workers benefit from a resumption of work, employers benefit from reduced worker absence, and the insurers benefit by reduced financial liability and less complex claims management processes. Furthermore, strategies for the prevention and management of work-related stress will be more effective when delivered through practical, balanced and transparent partnerships between all key stakeholders, a key element of a corporate citizenship approach.(WHO, 1995)

However, the stress exclusions present in the current Australian workers' compensation legislation appear diametrically opposed to the principles of CSR, by highlighting that an employer's obligation for a worker suffering mental stress extends only to where a direct link between the stress claim and occupational exposure is established. The multifactorial causation model for stress and psychological disorders often makes it difficult to differentiate between work and non-work contributory factors. Exclusion provisions that limit eligibility for a stress claim also exclude workers from the subsequent stress 
management interventions that would become available to the workers within the scope of a stress claim.

Instead of relying on exclusion provisions that inevitably deny the seriousness of mental health disorders among Australian workers, a cultural shift in how workers, employers and other stakeholders actively engage in addressing the problem of stress is needed. Clearly, all stakeholders, including legislators, have a responsibility to support, promote or contribute to the prevention and management of stress among workers. Adoption of a corporate citizenship approach can help promote this mutually of responsibility. However, while corporate citizenship remains a voluntary approach among organisations, legislators can promote the long term economic and social benefits to employers who may be focused on short term financial costs associated with stress among their workers. Possible future directions that promote activities using a corporate citizenship approach among the various stakeholders are discussed below.

\section{Future Directions}

In relation to stress related conditions in the community, cost and liability shifting is taking place between Federal and State and Territory Governments in Australia as well as between employers, private workers compensation insurers and private and public health insurers. The positioning and re-positioning of these agencies should not have a detrimental effect on injured workers. The data discussed above establishes that compensable stress related conditions are significant health issues in the broader community and that the threshold between a work related condition and a condition 
otherwise bought on by the normal exigencies are increasing blurred. It follows that a number of approaches might be considered. We offer these as broad concepts only.

First, consideration of the removal of all stress claim exclusion provisions would eliminate a proportion of litigation relating to the application of the exclusion clauses. In addition insurance costs of administration of those claims would fall away. Against this would be an expectation of rising claims and costs. As most stress related claims are multi-causal employers and insurers might also argue that this returns them to situation where they are carrying a disproportionate burden in relation to illnesses and disease which occur through non work-related matters. The prospects of turning back the clock would appear to be remote.

Second, instead of altering the existing legislation, insurers adopt a process of approval of claims on a 'without prejudice' basis in the short term. As an element in this process the insurer and employer would agree to allow a reasonable level of medical treatment and leave for any claim in order to reduce the anti-therapeutic effects of claim denial which usually results in delayed responses to care. Whilst there is not space to traverse the effects of delay and denial of claim upon worker health it is as much to note a body of literature now establish a clear link between failure to process a claim expeditiously and poor health and return to work outcomes. (Lippel, 1999; Strunin \& Boden, 2004;Beardwood et al, 2005; Kirsh \& McKee, 2003; Roberts-Yates, 2003) ${ }^{8}$ Reconciliation of the costs might take place after the claim has been accessed. The employer would need to be prepared to provide a safety net in relation to some medical costs. Some might argue that this process is informally in place already, as some 
enlightened insurers have adopted this approach. This policy could be formalised, particularly with larger government agencies, where sick leave entitlements are usually more generous. On the other hand informal arrangements such as the 'without prejudice' approach often involve intervention at a late stage of the development of the stress related condition. Earlier interventions are often warranted.

Third, in the case of larger employers adopting the innovative approach of unlimited sick leave may reduce the toxic effects of stress claims.(Robinson, 2003; NAB, 2008). This policy allows workers to claim unlimited leave for sickness including stress related conditions, on the condition that they are part of a managed return-to-work. This approach allows for earlier intervention by employers and avoids compensation claim frictions. Not surprisingly such a policy is generally only available to larger employers with strong in-house claims and human resource departments. It requires agreement with workers representatives as it usually forms part of a collective bargaining arrangement. Workers do not (and cannot) waive workers compensation rights, they simply choose an alternative industrial option offered by the employer. Importantly, managed sick leave allows the employer to terminate the workers employment where the worker is unable to resume duties.

Fourth, another option is the removal of exclusion provisions and the establishment of a co-operative fund between public health authorities (i.e. Medicare Australia), insurers and employers which would allow workers with stress related conditions to make claims through the employer; initially as a workers compensation claim to be accepted on without prejudice basis. The essence of this concept is again to reduce claimant friction costs and progress treatment at an early stage; thereby expediting worker access to 
tertiary level stress interventions. Contributions to the fund would reflect some estimate of workplace vs community/endogenous contribution to the condition, which characterises the assumption of shared responsibility and engagement with the issue of worker stress.

A fifth alternative proposal involves enlarging employer responsibility by removal of exclusion provisions and provision of financial support for employers who provide early intervention and 'without prejudice' approaches to work stress. This support would be in the form of taxation rebates or deductions for costs incurred in such programs. This approach would supplement already tax deductible employee costs. Consistent with principles of CSR, this option engages the government and employers to share responsibility and allows the focus to return to prevention of claims rather than exclusion of claims. Schemes of this kind are now appearing in Australia and the USA (Thompson, 2008). Based on a holistic approach to wellness in the workplace the Victorian Government, in 2008 established a chronic disease prevention screening program. This scheme encourages employers to provide health screening for employees which is partially subsidised by Government funds. In Victoria the funding is based on a dollar for dollar scheme with employers making an equal contribution which is also tax deductible.(Victorian WorkCover Authority, 2008)) This scheme is also being duplicated in Tasmania.(OHS Alert, 2008) These schemes serve as a model for a work-related stress programs. Importantly these schemes acknowledge the blurring between work and nonwork related incidents and the benefits to employers in focussing on employee wellness rather than placing excessive attention on statutory compliance and workers compensation rules. 


\section{Conclusions}

This article has discussed the prevalence of mental health disorders in Australia following the introduction of stress exclusion clauses. Requirements for the compensation of workrelated disease exist within the workers compensation legislation of the various jurisdictions in Australia. The introduction of exclusion clauses pertaining to stressrelated claims across all jurisdictions has limited worker access to compensation. The incidence and prevalence of stress claims since the introduction of the exclusions suggests they contribute little to the prevention and management of stress among workers. Associated costs due to presenteeism, absenteeism and decreased productivity have financial penalties to the employer, regardless of whether they accept liability for the claim. The continued increase in the costs and incidence of so called stress claims indicates that there is an asymmetry between the state of knowledge in relation to the prevention of poor mental health which indicates that attention should be directed and interpersonal relationships and organisation relations in the workplace. The article has indentified that precarious employment giving rise to increased worker vulnerability due to globalisation and new forms of employment contracts leading to perceptions of job insecurity are major stressors in the workplace. In Australia stress claims arising out of these factors are likely to present significant litigation challenges because all jurisdictions have imposed provisions which exclude claims based on stress arising from redundancy, redeployment, transfer and dismissal. Thus whilst there is research which indicates that change management is a major stressor and likely to cause incapacity unless properly 
managed, the safety net protections for income support have been removed. In short the legislative measures adopted are blunt instruments which aim to shift the costs of healt care and income support for mental disorders out of the workers compensation system into the public health and social security arena. This approach suggests that work and employment are causal factors in the development of these conditions. It also implies that employers should not bear the burden of any associated costs. This article advocates a rethink of this trend. It suggests that a range of options be considered, ranging from the preventative to funding non-adversarial compensation responses. Adoption of a corporate citizenship approach to the prevention and management of stress in the workplace is proposed, that extends beyond compliance with OS\&H risk reduction requirements to incorporate health promotion and which is not restricted by the exclusion clauses of the workers compensation legislation. Mutual responsibility, among all stakeholders, for the health and well-being of workers can be promoted through legislation, joint initiatives and financial incentives that promote a corporate citizenship approach to the management of stress among workers. 


\section{References}

Australian Bureau of Statistics Mental Health and Wellbeing: Profile of Adults, (1997) Australia

Commonwealth of Australia Canberra available at http://www.ausstats.abs.gov.au/Ausstats/subscriber.nsf/0/CA25687100069892CA25688900233CA F/\$File/43260_1997.pdf last viewed 11 November 2009 6-7

Australian Institute of Family Studies (2004) Australian Centre for the Study of Sexual Assault, Taking sexual harassment seriously Newsletter September No 4 available at http://www.aifs.gov.au/acssa/pubs/newsletter/n4pdf/acssa_news4_sexharass.pdf last viewed 19 January 2009.

Australian Institute of Health and Welfare Australia's Health 2002 (2002) AIHW Cat No AUS 25 Canberra available at http://www.aihw.gov.au/publications/index.cfm/title/7637 last viewed 11 November 2009 p 61

Australian Safety and Compensation Council (2006) Australian Workers' Compensation Law and it Application - Psychological Injury Claims Commonwealth of Australia Canberra available at http://www.safeworkaustralia.gov.au/NR/rdonlyres/6C3352C9-7A50-421C-AA40-

8B6F9DC10FFF/0/PsychInjuryClaimsReport.pdf $\quad$ last $\quad$ viewed 11 November $2009 \quad 9$ Recommendation 50 (ASCC)

Beardwood, B. A, Kirsh B, and Clark, N. J. (2005) Victims Twice Over: Perceptions and Experiences of Injured Workers 15 Qualitative Health Research 30, 31,

BHP Billiton Sustainable Development Case Studies available at http://www.bhpbilliton.com/bb/sustainableDevelopment/caseStudies/2007/frontEndLoadingOfHsec InIndonesiaCoalProjects.jsp. last viewed 23 February 2008. 
Bourbonnais, R., Jauvin, N. Dussault, J., Vezina, M. (2007) Psychological work environment, interpersonal violence at work and mental health among correctional officers International Journal of Law and Psychiatry 30 (4-5) 355-68

Buckmaster, L., and Pratt., A. (2005) 'Not on my account! Cost-shifting in the Australian health system. Parliamentary Library Research Note 6.2005-6 available at http://www.aph.gov.au/library/pubs/RN/2005-06/06rn06.htm last viewed 13th May 2008

Carroll, A.. (1979). A three dimensional conceptual model of corporate social performance. Academy of Management Review, Vol. 4 497-505.

Caulfield, N., Chang, D., Dollard. M., and Elshaug, C. (2004) A Review of Occupational Stress Interventions in Australia.' International Journal of Stress Management Vol 11 (2) 149-166.

Clark, M., Lewchuk, W., de Wolff, A., and King, A. (2007) This just isn't sustainable: Precarious employment; stress and workers health. International Journal of Law and Psychiatry 30 (4-5) 15

Danna, K., and Griffin, R. W. (1999) Health and Well-Bring in the Workplace; A Review and Synthesis of the Literature 25 (3) Journal of Management 357, 370-374,

Dollard M and Winefield A H (1996) Managing Occupational Stress: A National and International Perspective' International Journal of Stress Management Vol 2 (2) 69-83, 80

Dollard, M. F., and Winefield, H. (2002) Mental health: overemployment, underemployment, unemployment and healthy jobs Australian e-journal for Advancement of Mental Health Vol 1 Issue 3,3

Drucker, P. F. (1946) The Concept of the Corporation, New York and Toronto:

Einarsen, S. (1999) The Nature and Causes of Bullying at Work, 20 International Journal of Manpower , 57 
Einarsen, S., Hoel, H., Zapf, D., Cooper, C.L. (2003), The concept of bullying at work: the European tradition, in Einarsen, S., Hoel, H., Zapf, D., and Cooper, C. (Eds) Bullying and Emotional Abuse in the Workplace International Perspectives in Research and Practice.

European Agency for Safety and Health at Work (2007) Report - Expert Forecast on emerging psychosocial risks related to occupational safety and health available at http://osha.europa.eu/en/publications/reports/7807118/view last viewed 11 November 2009

European Agency for Safety and Health at Work FACT SHEET 74 available at http://osha.europa.eu/en/publications/factsheets/74 last viewed 9th November 2009. (EASHW, 2009b)

European Agency for Safety and Health at Work Psychosocial Risks available at http://osha.europa.eu/en/riskobservatory/risks/articles/psycho last viewed 9th November 2009 (EASHW, 2009a)

European Commission, Directorate-General for Employment, Industrial Relations and Social Affairs, (1998) Sexual harassment in the European Union last viewed at http://www.un.org/womenwatch/osagi/pdf/shworkpl.pdf 19 January 2009.

Field, T. (2003) Editorials Workplace Bullying - The Silent Epidemic 326 British Medical Journal 776

Goddard, T. (2004). Corporate Citizenship: Australian corporate attitudes towards stakeholder engagement. Journal of New Business Ideas and Trends, 2 (2), 12-28.

Greenberg, J. (2004) Stress Fairness to Fare No Stress: Managing Workplace Stress by Promoting Organisational Justice 33(4) Organizational Dynamics 352, 362 
Heads of Workers Compensation Authorities Preliminary Submission to the Commonwealth Reference Group on Welfare Reform $\left(28^{\text {th }}\right.$ January 2000) available at http://www.hwca.org.au/documents/dfacsdraft.pdf last viewed 13th May 2008

Henderson, S.,Andrews, G.,and Hall, W. (2000) Australia's mental health: an overview of the general population survey. Australian and New Zealand Journal of Psychiatry 34;197 -205, 204

Industry Commission (1994) Workers Compensation in Australia Report No 364 February 1994 Australian Government Publishing Service Canberra , 169-174

Kendall, E., Guy, L., Muenchberger, H., Murphy, P., and O'Neill, V. (2003). Occupational stress: A qualitative investigation of effective injury management available at http://www.workcover.wa.gov.au/PublicationsResearch/Research.htm last viewed 16 October 2006.

Kendall, E., Murphy, P., O'Neill, V., and Bursnall, S. (2000). Occupational stress: Factors that contribute to its occurrence and effective management available at http://www.workcover.wa.gov.au/PublicationsResearch/Research.htm. Last viewed 16 October, 2006.

Kenny, D. (1995). Common themes, different perspectives: A systems analysis of employeremployee experiences of occupational rehabilitation. Rehabilitation Counselling Bulletin, Vol. 39, $54-77$

Kirsh, B., McKee, P. (2003) The needs and experiences of injured workers: A participatory research study 21 Work 221-231,

Larsson, T, J., and Betts, N.J. (1996) The variation of Occupational Injury Cost in Australia: Estimates based on a Small Empirical Study Safety Science 24 (2 )143-155,151.

Lee, D. (2000) An analysis of workplace bullying in the UK 29(5) Personnel Review 593, 
Lippel, K. (1999) Therapeutic and Anti-Therapeutic Consequences of Workers' Compensation International Journal of Law and Psychiatry Vol 22 No 5-6 ,521-546,

Lippel, K..(1999) Workers Compensation and Stress. International Journal of Law and Psychiatry 22 (1) $79-89,88$

Lipscomb, H. J.,. Dement, M..,Epling, C. A.,. Gaynes, B. N.,,McDonald, M.,. and Schoenfisch, A. (2007) Depressive symptoms among working women in rural North Carolina: A comparision of women in poultry processing and other low-wage jobs. International Journal of Law and Psychiatry 30 (4-5) 284-298

Macklin, D. S., Smith, L. A.,and Dollard, M. F. (2006) Public and private sector work stress: Workers compensation, levels of distress and job satisfaction, and the demand-control-support model. Australian Journal of Psychology Vol 58 (3) 130-143

Marchand , A. (2007) Mental health in Canada: Are there any risky occupations and industries? International Journal of Law and Psychiatry 30 (4-5) 272 -283

Mayhew, C., and Chappel, D. (2007) Workplace violence: An overview of patterns of risk and the emotional/stress consequences on targets. International Journal of Law and Psychiatry 30 327-339.

Medibank Private (2008) The Cost of Workplace Stress in Australia August 2008 available at http://www.medibank.com.au/Client/Documents/Pdfs/The-Cost-of-Workplace-Stress.pdf $\quad$ last viewed 14th September 2009

Meehan, J., Meehan, K., and Richards, A. (2006)Corporate Social Responsibility, Social Capital; Corporate Strategy International Journal of Social Economics 33, 5/6 386-398.

Michie, S. (2002) Causes and Management of Stress at Work 59 Occupational Environment Medicine 67 
National Bank of Australia (2008) Annual Financial Report - Additional Financial Information available at http://nab2008annualreports.textpacific.com.au/corporate_responsibility_review/our last viewed 15th January 2009

Niemeyer, L O. (1991) Social Labeling, Stereotyping and Observer Bias in Workers' Compensation: The Impact of Provider-Patient Interaction on Outcome 1 Journal of Occupational Rehabilitation 4, 251-269 at 264,

OHS Alert (2008) 'Health Program for Tasmanian public servants announced in State Budget' OHS Alert $13^{\text {th }}$ June 2008 accessible by subscription at www.ohsalert.com.au (copies held on file)

Oomens, S. Geurts, S. and Scheeper, P. (2007) Combining work and family in the Netherlands: Blessing or burden for one's mental health? International Journal of Law and Psychiatry 30 (4-5) 369-384

Parslow, R. A.,Jorm, A. F. Christensen, H., Broom,D.H., Strazdins, L., and D’Sousa, R. M. (2004) The impact of employee level and work stress on mental health and GP service use; an analysis of a sample of Australian government employees. BMC Public Health 4;41

Porter, M., and Kramer, M. (2006). Strategy and Society: the link between competitive advantage and corporate social responsibility. Harvard Business Review, 84 (12), 78-92.

Pyöriä, P (2003) Knowledge work in distributed environments: issues and illusions. New Technology, Work and Employment, 18 (3) 166-180

Quinlan, M. (2007) Organisational restructuring/downsizing, OHS regulation and worker health and well-bring International Journal of Law and Psychiatry 30 (4-5) 385-399

Roberts-Yates, C. (2003) The concerns and issues of injured workers in relation to claims/injury management and rehabilitation: the need for operational frameworks. 25 Disability and Rehabilitation 16, 898-907 
Robinson,R. (2003) 'Bank launches pooled sick leave' The Age 11 November 2003,

Safe Work Australia Home Page available at http://safeworkaustralia.gov.au last viewed 11 November 2009

Safe Work Australian (2009) Data and Statistics Online Statistical Database (NOSI) http://www.safeworkaustralia.gov.au/swa/AboutUs/Publications/DataandStatistics.htm last viewed 11November 2009

Saunders, P., Huynh, A.,. Goodman-Delahunty, J. (2007) Defining workplace bullying behaviour professional lay definitions of workplace bullying. International Journal of Law and Psychiatry 30 (4-5) 340-354

Seifert, A.., M Messing, K., Riel, J., and Chatigny, C. (2007) Precarious employment conditions affect work content in education and social work: Results of work analysis. International Journal of Law and Psychiatry 30 (4-5), 299-310

Strunin, L., and Boden, L The Workers’ Compensation System: Worker Friend or Foe? (2004) 45 American Journal of Industrial Medicine 338-345, 345

Sullivan, C. (2003). What's in a name? Definitions and conceptualisations of teleworking and homeworking. New Technology, Work and Employment, 18 (3), 158-165

Thompson B (2008) "Wellness Comp": Is there a place for Health Promotion Programs in Workers Compensation? Workers Compensation Issues Report 2008 at http://www.ncc.com/ncci/web/news/pressrel/News_Room/Issues_Report_Articles_htm last accessed 13th May 2008

Tomaras, J., and Nielson, L. (2007) Safety Rehabilitation and Compensation and Other Legislation Amendment Bill 2006 Bills Digest 26 March, No 122 2006-7 ISSN 1328-8091 at 
http://www.aph.gov.au/library/pubs/bd/2006-07/07bd122.pdf 1 last accessed $18^{\text {th }}$ June 2008 who assert that the amendments would result in savings to the Commonwealth.

Victorian WorkCover Authority Annual Report (2008) avaialable at http://www.worksafe.vic.gov.au/wps/wcm/resources/file/eb8a0044bd56ea1/WorkSafe\%20Annual\%20Rep ort\%202008.pdf last viewed 11 November 2008, 32

Williams, C. (2003) Sources of Workplace Stress 4(6) Perspectives on Labour and Income online at http://www.statcan.gc.ca/pub/75-001-x/00603/6533-eng.html last viewed 9th November 2009

Willness, C. R,., Steel, P., and Lee, K. (2007) A meta-analysis of the antecedents and consequences of workplace sexual harassment 60 Personnel Psychology 127.

WorkCover WA available at http://www.workcover.wa.gov.au last viewed 11 November 2009

World Health Organisation (1992)The ICD-10 Classification of Mental and Behavioural Disorders Clinical descriptions and diagnostic guidelines. World Health Organisation Geneva

World Health Organisation. (1995). The Jakarta declaration on health promotion into the 21st century, available at http://www.who.int/dsa/cat95/zjak.htm. last viewed 21 April, 2002.

Work Safe Victoria (2009) Prosecution summaries found at <http://www.workcover.vic.gov.au/wps/wcm/connect/WorkSafe/Home/Forms+and+Publications/F orms+and+Publications+Results?searchAny=prosecutions $>$ at $15^{\text {th }}$ June 2009.

Zapf D (1999) Organisational, work group related and personal causes of mobbing/bullying at work 20(1/2) International Journal of Manpower 70,

\section{Cases Referred}

Abrahams v St Virgil's College (unreported, SC(Tas), Underwood, J, 53/1998, 11 May 1998) 
Allman v Major Finance and Engineering Pty Ltd (unreported, County Court, judgment 14 March 1997).

Arthurv Comcare [2004] AATA 241

Asker v WorkCover Corporation [2004] SAWCT 115.

Boyd v WorkCover [2004] SAWCT 76

Catholic Care v Wrafter (unreported, CM(WA), 60/96, 28 October 1996)

Clarke v Quinns Baptist College Inc [1999] WAIRC 125

Comcare v Chenhall (1992) 109 ALR 361 (emphasis added)

Comcare v Mooi (1991) 23 ALD 572

Dawe v Twin Towns [2000] NSWCC 27

Delongville v South Australia Police [2004] SAWCT 31

Department of Education \& Training v Sinclair [2004] NSW WCC 90.

Department of Education \& Training v Sinclair [2005] NSWCA 465

Department of Education v F [2004] TASWRCT 43

Dimitriou v Australian Postal Corporation (unreported, AAT, No V91/383, 14 January 1993)

Federal Broom Co Pty Ltd v Semlitch (1964) 110 CLR 626

Fernandez v South Australia (unreported, SC (SA), No. SCGRG 93/1558, 28 July 1994)

Golds v Comcare [1999] FCA 1481 
Gorrie v Department of Education and Children's Services [2005] SAWCT

Hatzimandis v ANI Corp Ltd (1992) 173 CLR 473

Housing Industry Assoc Ltd v Murten [2004] WASCA 139.

Housing Industry Assoc v Murten (unreported, CM (WA), 231/01, 26 November 2002).

Jenkins v Western Australian Department of Training [1999] WASCA 199.

Kavanagh v Commonwealth (1960) 103 CLR 547

Kerrison v New South Wales Technical and Further Education Commission [2003] NSWIRC 76

Kershaw v Department of Employment, Training and Further Education [2003] SAWCT

Levi v Unisure Pty Ltd (University of Adelaide [2000] SASC 167.

Manly Pacific International Hotel v Doyle [1999] NSWCA 465.

Mansell v Bellorana Hostel (2000) 19 NSWCCR 572

Mercer v ANZ Banking Group Ltd (2000) 48 NSWLR 740

Mitsubishi Motors Australia v Lupul [2004] SAWCT 130

Mokta v Metro Meat International Ltd [2005] WASCA 143 at paras 30 - 39

Pawluk v WorkCover [2004] SAWCT 85

Peters v Comcare [2004] AATA 435

Pirie v Franklins Ltd [2001] NSWCC 167

Place v Commissioner for Public Employment [2002] SAIRC 70 
Popovski v Ericsson Pty Ltd (unreported, SC (Vic), 4516/98, 4 September 1998).

Re Awad v Comcare (1996) 45 ALD 400

Re Bartlett v Comcare (1996) 40 ALD 709

Re Choo v Comare (1995) 39 ALD 399

Re Frank v Comcare (1996) 41 ALD 597

Re Quarry v Comcare (1997) 47 ALD 113

Re Rizkallah v Australian Postal Corporation (1996) 137 ALR 690

Roberts v Dorothea Slate Quarries Co Ltd [1948]2 All ER 201

Rukavina v Bridgestone Australia Ltd [2005] SAWCT 79

State Energy Commission v Van-Zyl (unreported, SC(WA), SCL4879, 27 April 1983)

Stewart v NSW Police Service (1998) 17 NSWCCR 202

Trewin v Comcare (1998) 84 FCR 171

Tubemakers of Australia Ltd v Fernandez (1976) 10 ALR 303

University of Tasmania v Cane (1994) 4 Tas R 156

Western Australian Industrial Union of Workers v Swan [2000]WAIRC 184

Zechner v Department of School Education [1999] FCA 445

Zickarv MGH Plastic Industries Pty Ltd (1996)187 CLR 310 